\title{
The integrated effect between phosphorus fertilizing levels and biological control on damping - off, root rot diseases and its reflection on an improving growth and fresh pods yield of priming and non-priming pea seeds
}

\author{
M. F. Zaki ${ }^{1}$, R. S. R. El-Mohamed ${ }^{2}$, M. S. S. El-bassiony ${ }^{3,{ }^{*}}$ and Y. I. Helmy ${ }^{\mathbf{1}}$ \\ ${ }^{1}$ Vegetable Research Department, National Research Centre, Dokki, Cairo, Egypt \\ 2 Plant Pathology Department, National Research Centre, Dokki, Cairo, Egypt \\ ${ }^{3}$ Horticulture Department, Faculty of Agriculture, Al-Azhar University, Assiut, Egypt \\ * Correspondence: El-bassiony@azhar.edu.eg (M. El-bassiony)
}

\begin{abstract}
Two experiments were conducted in newly reclaimed soil for two successive winter seasons during 2014/2015 and 2015/2016 at El-Nobaria region, Beheira, Egypt on two peas cultivars, i. e. Little Marvel (LM) and Master B (MB). The purpose of this study is to improve the efficiency of biological seed treatments such as bio-priming and seed coating with $T$. harzianum in control of root rot disease and improve vegetative growth of pea plants under field conditions. In

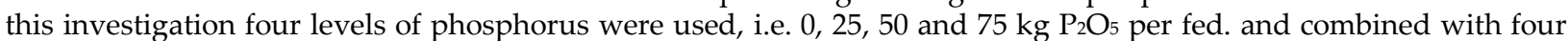
biological seed treatments, i.e. untreated seeds (control); treated seeds with bio-priming, priming and coated by $T$. harzianum. Pea root rot disease incidence was recorded after 30 and 60 days of sowing. Results showed that the highest vegetative growth characters, total green pods yield and good quality were obtained by plants of Master P (MB) cultivar compared to Little Marvel (LM). The highest values of previous characters were recorded by plants which

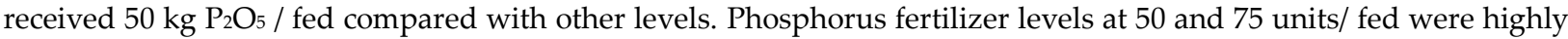
effective then 25 units/ feddan in decreasing the root rot \% infection and reduction in the incidence of root rot of pea plants. Recommend by using pea seeds of cv. Master B in cultivation and using bio-primed seeds with bio-control agents like T. harzianum or T. viride or T. asperellum should be utilized for managing seed borne pathogens and fertilizing pea plants by adding mineral phosphorus fertilizer.
\end{abstract}

Keywords: Bio-priming; Damping off; Fresh pods yield; Fusarium solani; Rhizoctonia solani; Root rot Pea.

\section{INTRODUCATION}

Pea (Pisum sativum L.) is one of the most important leguminous crops for exportation and local consumption in Egypt. Seeds of pea are used a fresh and dry for cooking and industries. It is a crop cultivated in scattered areas for exportation so, it became of great importance to study its cultivars, fertilization and diseases. Growing pea in the newly reclaimed soils is faced by various problems, such as root rot disease in many locations and low amounts of available nutrients. Pea plants proved vulnerable to root diseases caused by certain soil borne fungi, i. e. Fusarium solani, Rhizoctoni solani, F. oxysporum, Pythium spp, Sclerotium rolfsii and Phytophthora cactorum which attack roots causing damping off and root rot diseases as well as substantial losses in yield of pea (Abda et al., 1992; Persson et al., 1997; Ragab et al., 1999; Xue, 2003).

The function of phosphorus in plants is very important. It helps a plant convert other nutrient into usable building blocks with which to grow. Phosphorus is one of the main three nutrients most commonly found in fertilizers and is the "P" in the NPK balance that is listed of fertilizers (Lovatt and Mikkelsen, 2006).

Srivastava et al. (1998) stated that the high requirement for $(\mathrm{P})$ in legumes is consistent with the involvement of $\mathrm{P}$ in the high rates of energy transfer that must take place in the nodule. In addition, phosphorus has an enhancing impact on plant growth and biological yield through its importance as energy storage and transferee necessary for metabolic processes.

Togay et al., (2008) pointed that the highest growth parameters of lentil plants were obtained from $60 \mathrm{Kg} \mathrm{P} \mathrm{ha-1.}$

Agegnehu (2009) found that application of phosphate fertilizer at the rates of 10, 20 and 30 $\mathrm{kg} \mathrm{P}$ ha ${ }^{-1}$ increased mean grain yield of field pea by 36,67 and $57 \%$, respectively compared to the control. Many investigators studied the role of phosphorus in fertilizing pea plants (Gubbels, 1992; Karamanos et al., 2002; Malakooti and Nafisi, 1995; Murat et al., 2009 and Nadeem et al., 2003; Manore and Altaye 2018).

Few studies examined the possible utilization of some agricultural practices such as fertilization or soil amended with chelating elements (calcium and sulphur) in control of soil borne plant pathogens on several plants. Graham, 1983 found that moderate phosphorus levels tend to decrease disease incidence in particular fungal diseases such as pythium root rot whereas, very high or low levels tend to increase disease incidence.

Priming of seeds is a well-established technology to improve speed and uniformity of germination. Seed priming is an age old practice exercised by Greek. They resoaking of cucumber seeds in milk or water to make then germinate earlier and Vigorously (Evanari, 1984). The term 
"seed priming" was proposed by Heydecker et al. (1973) for the soaking drying seed treatments. This technique is a treatment applied prior o sowing in a specific environment where in seeds are partially hydrated in pure water or osmatic solution for a predetermined time interval, to a point of germination process initiation without visible symptom of radical emergency (Kaur, 2002) and (Giri and Schilinger, 2003). Seed priming involves taking seed through the early stages of the germination process. Diring the phase I, under moderate temperature and moisture, seed takes up water. During phase II, the biochemical processes are activated in order to allow the necessary germination related metabolic acclivities to take place, but radical emergence is prevented by limiting the seed water content (Bradford, 1986). The seeds were tacked part way through phase II and then dried before the root can emerge from the seed. The need for drying to facilitate the handling, storage and sowing of seeds (Demir, 2003). Once conditions are appropriate in field, phase III can continue, germination occurs in a much shorter time.

Olant seeds can be subjected to different priming treatments such as polyethylene glycol or sorbitol (Osmo-priming), abscisic acid (Hormonal-priming) and Calcium or sodium chloride (Holo-priming) etc. (Kalpanan et al., 2015).

When dry seeds are treated with a bio-control agent, they called (Seed coating treatment) while when primed seeds are treated with the biocontrol agent, they called (Seed bio-priming). In solid matrix priming, seeds are mixed with a solid material and water. This soild material should be had a water-holing capacity such as a ground Leonardite shale or Carboxy methyle cellulose (CMC) (Taylor et al., 1988).

Controlling root disease mainly depends on fungicidal treatments. Meanwhile, fungicidal applications cause hazards to human health and increase environmental pollution. Therefore, there are needed to alternative fungicidal seed treatment. The application of biological seed treatments alone or in combination with other disease control approaches such as fungicides, physiological process and soil amendments and priming proved to be successful for controlling various plant diseases on many crops.

Biological control is proposed to be an effective and non-hazardous strategy to reduce crop damage caused by plant pathogens. Application of biological control using antagonistic microorganisms against seed and root rot pathogens proved to be successfully and its efficiency in controlling root rot pathogens and improving plant growth, total yield and nutritional values of many vegetable crops (El-
Mohamedy et al, 2014). Coating seeds of many crops with bio control agents such Trichoderma spp., Bacillus subtillus, Psedomonas fluorescens was the most effective treatments for controlling seed and root pathogens (Nayaka et al., 2008; Begum et al., 2011).

Pea seeds coated with Trichoderma koningii and $T$. viride were the most effective treatments for controlling pea root rot pathogens (Lacicawa and Pjeta, 1994; Benhamou et al., 1996; Ragab et al., 1999; Rauf, 2000; Xue, 2003). Trichoderma spp. is widely used as bio-control agent that enhances plant growth as well as inhibits phytopathogens (Vivek et al., 2016).

Seed bio priming is an advance technique of seed treatment that involves application of beneficial microorganisms on seed surface followed by seed hydration. Seed bio-priming is an ecological management strategy to control many seed and soil-borne pathogens which provide an alternative to chemical treatment. Seed bio-priming enhance the initial step of plant development by increased seed germination and provide protection before seedling emergence.

Recently, bio-priming as biological seed treatment that integrate biological and physiological aspects of disease control was used alone or in combination with soil amendments as alternative methods for controlling many seed and soil borne pathogens (Harman and Taylor, 1988; Warren and Bennett, 1999; El-Mohamedy, 2004; El-Mohamedy et al., 2006; El-abd et al., 2013; El-Mohamedy and Abd-Alla, 2013 and Vivek et al., 2016).

The combination between seed coating with bio control agents and chitosan were the most effective for controlling pea root rot disease and increasing growth and yield of pea plant (Abd ElKareem, 2002). Ragab et al., 1999 noticed that combination between fungicides (Rizolex-T or Topsin-M) and Bacillus subtillis gave the best significant reduction in pea root rot disease caused by Rhizoctoni solani, Phytophthora spp. and Fusarium solani.

The purpose of the present study is to improve the efficiency of biological seed treatments such as bio-priming and seed coating with $T$. harzianum in control of root rot disease and improve vegetative growth of pea plants under field conditions.

\section{MATERIALS AND METHODS}

Two drip irrigated field experiments were carried out on pea (Pisum sativum L.), Fam. Leguminous in an area of newly reclaimed land the experimental farm of National Research Centre, at El-Nobaria, Beheria Governorate, Egypt, during the two successive winter seasons of 2014/2015 and 2015/2016.

The aim of this work was evaluation of two pea cultivars under open field conditions and 
levels of phosphorus fertilizer to resistance root rot and damping off diseases. Random soil samples were collected before planting from the top layer (0-30 cm depth) for physical and chemical analysis. Soil analysis and the main analytical data of the soil are presented in Table (1), following the procedures of Page et al. (1982) and Klute (1986). On the other hand, organic manure (compost) contents of total and available $\mathrm{N}, \mathrm{P}$ and $\mathrm{K}$ and some micro-elements were presented in Table (2) following the procedures of Page et al., (1982).

The soil of the experimental plots was carefully prepared, in each growing season. Ditches of $20 \mathrm{~cm}$ depth and $40 \mathrm{~cm}$ width were prepared in the sites of drip irrigation lines; calcium super phosphate and organic manure [compost at rat of $60 \mathrm{~N}$ units per fed.] were mixed and added in the ditches then covered by soil. Ammonium sulfate $(20.6 \% \mathrm{~N})$ was used as a source of nitrogen, calcium super phosphate (15.5 $\left.\% \mathrm{P}_{2} \mathrm{O}_{5}\right)$ as a source of phosphorus at the rate of 0 , 25, 50 and $75 \quad \mathrm{P}_{2} \mathrm{O}_{5}$ unit/fed and potassium sulphate $\left(48 \% \mathrm{~K}_{2} \mathrm{O}\right)$ was used as a source of potassium at the rate of $50 \mathrm{~K}_{2} \mathrm{O}$ unit/fed. The quantities of the mineral fertilizer were splinted into three equal doses and applied as dressing (30, 60 and 90 days after sowing) beside plants. Drip irrigation lines were spread over the ditches. Soil was irrigated continuously three days before sowing. Seeds were sown on the two sides of each row $75 \mathrm{~cm}$ in width and $50 \mathrm{~cm}$ apart. Each plot included three rows, plot area was $10.5 \mathrm{~m}^{2}$. Seeds were sown in the open field on the first week of December in the two seasons of 2014/2015 and 2015/2016.

\section{The causal pathogens:}

Samples of pea seedlings and plants showing damping-off and root rot disease symptoms were collected from different pea field of NRC farm were subjected to isolation trails of the causal organisms. The purified isolated fungi were grown on PDA media and identified according to cultural and microscopic characters as described by Gilman (1957), Barrent and Hunter (1972), Nelson et al. (1983). The pathogenic ability of isolated fungi to induce damping off and root rot infection of pea plants was tested.

Table 1. Physical and chemical properties of the experimental soil during the two seasons of 2014/2015 and 2015/2016.

\begin{tabular}{|c|c|c|c|c|c|c|c|c|c|c|c|c|}
\hline \multicolumn{13}{|c|}{ A. Physical properties } \\
\hline Season & \multicolumn{3}{|c|}{ Sand (\%) } & \multicolumn{4}{|c|}{ Clay (\%) } & \multicolumn{2}{|c|}{ Silt (\%) } & \multicolumn{3}{|c|}{ Soil texture } \\
\hline $2014 / 2015$ & \multicolumn{3}{|c|}{91.20} & \multicolumn{4}{|c|}{5.10} & \multicolumn{2}{|c|}{3.70} & \multicolumn{3}{|c|}{ Sandy } \\
\hline $2015 / 2016$ & \multicolumn{3}{|c|}{92.33} & \multicolumn{4}{|c|}{4.78} & \multicolumn{2}{|c|}{2.95} & \multicolumn{3}{|c|}{ Sandy } \\
\hline \multicolumn{13}{|c|}{ B. Chemical properties } \\
\hline \multirow{2}{*}{ Season } & \multirow{2}{*}{$\begin{array}{c}\text { E.C. } \\
\left(\mathrm{mmohs} / \mathrm{cm}^{3}\right)\end{array}$} & \multirow[t]{2}{*}{$\mathrm{pH}$} & \multirow{2}{*}{$\begin{array}{l}\mathrm{OM} \\
(\%)\end{array}$} & \multirow{2}{*}{$\begin{array}{c}\mathrm{CaCo} 3 \\
(\%)\end{array}$} & \multicolumn{4}{|c|}{ Cations ( Meq./L ) } & \multicolumn{4}{|c|}{ Anions ( Meq./L ) } \\
\hline & & & & & $\mathrm{Ca}^{++}$ & $\mathrm{Mg}^{++}$ & $\mathrm{Na}^{+}$ & $\mathrm{K}^{+}$ & $\mathrm{CO}_{3--}^{--}$ & $\mathrm{HCO}_{3}$ & $\mathrm{Cl}^{-}$ & $\mathrm{SO}_{4}^{--}$ \\
\hline $2014 / 2015$ & 0.30 & 7.80 & 0.30 & 10.2 & 1.00 & 0.20 & 0.80 & 0.39 & Nil & 1.00 & 1.00 & 0.39 \\
\hline $2015 / 2016$ & 0.50 & 7.88 & 0.50 & 10.8 & 1.20 & 0.26 & 0.82 & 0.43 & Nil & 1.10 & 1.20 & 0.41 \\
\hline
\end{tabular}

Table 2. Chemical analysis of compost manure used in 2014/2015 and 2015/2016.

\begin{tabular}{lcc}
\hline Mineral content & $(2014 / 2015)$ & $(2015 / 2016)$ \\
\hline $\mathrm{N} \%$ & 2.20 & 2.46 \\
$\mathrm{P} \%$ & 0.91 & 1.80 \\
$\mathrm{~K} \%$ & 1.40 & 2.37 \\
$\mathrm{C} / \mathrm{N}$ ratio & 4.29 & 7.40 \\
D.M \% & 28.1 & 46.5 \\
O.C \% & 16.3 & 27.00 \\
C ppm & 1.10 & 0.90 \\
F ppm & 0.89 & 0.92 \\
Humidity & 17.20 & 17.48 \\
\hline
\end{tabular}

\section{Field experiment}

These experiments were carried out under open field conditions. The farm land has been known as heavily natural contaminated with root rot pathogens. Treatments were conducted in split - split plots design with three replicates.

\section{Treatments of the experiment were as follows}

a) Cultivars: Two cultivars of pea, i.e. Little Marvel (LM) and Master B (MB).

b) Phosphorus levels:__Four levels of phosphorus fertilizer, i.e. $0,25,50$ and $75 \mathrm{P}_{2} \mathrm{O}_{5}$ unit/feddan were applied individually or in combination with seed treatments. Calcium 
super phosphate $\left(15.5 \% \mathrm{P}_{2} \mathrm{O}_{5}\right)$ as a source of phosphorus was applied.

c) Biological seed treatments: Four seed treatments were as follow: 1 . Non treated seeds (control), 2. Bio-primed seeds. 3. Primed seeds. 4. Seeds coated with T. harzianum.

Seed Priming and bio-priming: Seeds of two cultivars, i.e. Little Marvel (LM) and Master B (MB) were initially washed with tap water to remove microbial load. Seeds were primed according to methods described by Osborn and Scharoth (1989) and Harman and Taylor (1988) by soaking in $1 \%$ Carboxy methyl cellulose (CMC) in Erlenmeyer flask on a rotary shaker set at $150 \mathrm{rpm}$ for $4 \mathrm{hrs}$.

Seed bio-priming with Trichoderma harzianum: Seeds of pea were surface sterilized with $1.5 \%$ sodium hypochlorite $(\mathrm{NaOCl})$ for 5 minutes and rinsed thrice with autoclaved distilled water and dried under laminar air flow on autoclaved blotting paper (Jain et al., 2012). CMC 1\% supplemented with spore suspension of $T$. harzianum $\left(3 \times 10^{6}\right.$ spore $\left./ \mathrm{ml}\right)$ were subsequently added to seed during priming process for 30 minutes to bio-primed seeds. Primed and bioprimed seeds were shaken at $150 \mathrm{rpm}$ for 12 hour, then dried and placed in polyethylene bags for further studies.

Seeds treated with CMC only acted as control. The seeds were dried in laminar air flow for $2 \mathrm{~h}$ (Singh et al., 2013a). The seeds were placed in the moist chamber at $98 \%$ relative humidity and $28-$ $30^{\circ} \mathrm{C}$, and maintained for $24 \mathrm{~h}$ (Jensen et al., 2004).

Seed coating: Pea seeds were immersed for 30 min. in a suspension of Trichoderma harzianum. This bio control agent was previously isolated from a rhizosphere soil of healthy pea plants and antagonistic ability against some root rot pathogens was recorded. Spore suspension of $T$. harzianum was prepared from 7- day old cultures grown in PDA medium. Fungal spores were gently scraped from PDA cultures in water and filtered through nylon mesh (38 Mm). All spores solution were adjusted with sterile water to density concentration of $1 \times 10^{6} \mathrm{cfu} / \mathrm{ml}$. Seeds were coated by shaking $1 \mathrm{~g}$ of seeds per treatment with $4 \mathrm{ml}$ of the adjusted conidial suspension on a shaker (1 KA vibrax, $1 \mathrm{KA}$ works, Wilmington No. 1 for $10 \mathrm{~min}$. at $130 \mathrm{rpm}$. Subsequently, the seeds were air-dried on filter paper for $1 \mathrm{~h}$ in a laminar flow hood before planting (Nayaka et al., 2008).

Experimental design: Each replicate included 32 treatments which were the combinations of two cultivars of pea and four levels of phosphorus fertilizer treatments with four seed treatments. The split-split plots design with three replicates was used. The main plots were cultivar treatments, whereas, the sub plots were assigned for the phosphorus levels and biological seed treatments were placed in the sub-sub plots. Data were subjected to proper statistical analysis according to Snedecor and Cochran, 1980.

\section{Data recording}

\section{Biological data}

The percentage of plot stand, i. e. the number of plants which had emerged as a percentage of those that were originally planted was determined 14 days after planting, and then the percentage of dead or damped seedlings was calculated (Hwang et al., 1996). The pea root-rot incidence percentage was determined 30-60 days after planting. Sample plants pulled out along a diagonal transect across the field, five plants per site and 100 plants per field. Root-rot incidence percentage was scored using the following formula: No. of diseased plants/ No. of plants observed x 100 (Kobriger and Hagedorn, 1983). The percentage of survival plants in each particular treatment was calculated. Moreover, the beneficial effects of the different treatments on vegetative growth of the two cultivars of pea plants were investigated.

\section{Vegetative growth characteristics}

Random samples of five plants from all treatment were harvested at maturing stage and the following data were recorded during the two seasons.

1. Plant length $(\mathrm{cm})$.

2. Leaves number per plant.

3. Branches numbers/ plant.

4. Fresh weight of leaves, stems, pods and seeds ( $\mathrm{g} /$ plant).

5. Dry weight of leaves, stems, pods and seeds ( $\mathrm{g} /$ plant).

\section{Total fresh pods yield}

All the plants every treatment was harvested at maturing stage and the following data were recorded, i. e. total green yield (ton/fed.).

\section{RESULTS AND DISCUSSION}

\section{Effect of cultivars (Classification reactions)}

\section{Damping-off and root rot incidence}

Pea root rot disease incidence was recorded after 30 and 60 days of sowing. Results in Table (3) show that pea of cv. Master B (MB) reduced the incidence of root rot until 60 days compared with cv. Little Marvel (LM) during two seasons. MB cultivar was highly effective in decreasing the percentage of root rot infection. The highly percentages of survival plants were recorded with of MB cultivar compared with LM cultivar which records the low survival percentage. These results are in accordance with those observed by El-Mohamedy and Abd-El-Baky, (2008). 


\section{Vegetative growth and total pods yield}

The results indicated that statistical variations were recorded in the vegetative growth of the tested two pea cultivars (Table, 4). The results indicated that $\mathrm{MB}$ cultivar was the best in its vegetative growth, i.e. leaves number; fresh weight of leaves, pods and seeds and dry weight of leaves, pods and seeds as well as total fresh pods yield (ton/fed) compared with LM cultivar. Plant length, branches number and stems fresh weight characters were not significant. The lower values of vegetative growth were recorded by LM cultivar.

These results were similar and true in the two seasons. Similar results were reported on pea by many investigators (Badr et al., 2015) on pea indicated that cv. Master B showed higher values for most of the growth traits and yield parameters in comparison with cv. Little Marvel. The hybrids of cV. Master B significantly surpassed the highest parental genotypes for days to flowering and fruiting and also productivity.

\section{Effect of phosphorus fertilizer levels}

\section{Damping-off and root rot incidence}

Data presented in Table (5) clear that pea root rot disease incidence was recorded after 30 and 60 days of sowing. Results show that all phosphorus levels reduced the incidence of root rot until 60 days on pea plants during two seasons. Phosphorus fertilizer levels at 50 and 75 $\mathrm{P}_{2} \mathrm{O}_{5} /$ feddan were highly effective then 25 units/ feddan in decreasing the percentage of root rot infection of pea plants during two seasons. The treatment of $75 \mathrm{P}_{2} \mathrm{O}_{5}$ reduced the incidence of pea root rot by $26.88,31.80 \%$ and $25.24,31.25 \%$ in pea plants compared with 0 unit/ feddan (control) after 30 and 60 days after sowing date during two seasons, respectively. Meanwhile, the treatment of $75 \mathrm{P}_{2} \mathrm{O}_{5} /$ feddan cause a reduction in the incidence of pea root rot estimated by $34.91 \%$, $40.03 \%$ and $32.35 \%, 39.61 \%$ on pea compared with control after 30 and 60 days of sowing during two seasons, respectively. The highly percentages of survival pea plants were recorded with 50 and $75 \mathrm{P}_{2} \mathrm{O}_{5}$ unit treatments. Many investigators reported that, increasing phosphorus rates above the level needed to grow the crop can increase the severity of Fusarium wilt in muskmelon (Jones et al., 1989).

\section{Vegetative growth and total fresh pods yield}

Data presented in Table (6) show that the effect of phosphorus levels on vegetative growth characters and total fresh pods yield of pea plants expressed as plant length, leaves and branches number/ plant, as well as fresh and dry weight of leaves, stems, pods and seeds and total fresh pods yield (ton/fed). The results revealed that vegetative growth of pea plants was enhanced by increasing phosphorus fertilizer rates up to $50 \mathrm{~kg}$ $\mathrm{P}_{2} \mathrm{O}_{5} /$ feddan. Moreover, the highest values of vegetative growth characters were obtained from application of mineral phosphorus fertilizer at the rate of $50 \mathrm{~kg} \mathrm{P}_{2} \mathrm{O}_{5} /$ fed compared with other phosphors rates treatments in both seasons. Similar results with phosphorus application have been reported by Parasad et al. (1989); Sharma et al. (1997); Verma et al. (1997) and Dass et al. (2005). These results were in agreement with those Dass et al. (2005) reported that increasing phosphorus levels from 0 to $75 \mathrm{~kg} \mathrm{P}_{2} \mathrm{O}_{5}$ /ha significantly improved the growth, yield and net returns of the crop. Application of $75 \mathrm{~kg} \mathrm{P}_{2} \mathrm{O}_{5} /$ ha resulted in the highest green pod yield of $43.33 \mathrm{q} / \mathrm{ha}$.

Phosphorus is an important nutrient that is essential for plant growth and development which is generally present in unavailable form. Many microorganisms including Trichoderma spp. produce organic acids and phosphatase that solubilize the unavailable phosphate to available phosphate that can be easily absorbed by plants. Trichoderma spp. also helps to increase the nitrogen use efficiency in plants (Rakshit et al. 2015).

\section{Effect of seed treatments}

\section{Damping-off and root rot incidence}

Percentages of damping-off and root rot infection after 30 and 60 day from sowing were recorded. Results in Table (7) indicated that all seed treatments reduced the percentage of preemergence damping-off in pea plants as compared with control (non-treated seeds). The most effective type of seed treatment is biopriming flowed by seed coating treatment. Biopriming caused reduction of root rot disease incidence reach to 81.24 and 73.71 at pre emergence stage during two seasons, respectively and 71.46, $72.09 \%$ and $75.78,75.03 \%$ of pea plants at post emergence stage after 30 and 60 days after sowing date during two seasons, respectively. As bio-priming and seed coating treatments caused a reduction of root rot disease by $71.46,55.86 \%$ and $75.78,57.99 \%$ of pea plants during the first season, respectively and 72.09 , $52.71 \%$ and $75.03,49.83 \%$ of pea plants during the second season, respectively.

These results are in accordance with those observed by Tu, 1992; Persson et al., 1997; ElMohamedy and Abd-El-Baky, 2008 and Vivek et al., (2016) on peas. El-Mohamedy and Abd-ElBaky (2008) evaluated the effect of different types of seed treatments on control of root rot disease and reported that seed priming with Trichoderma harzianum, Bacilus subtilis and Psedomonas fluorescens was effective in control of root rot pathogens and highest percent of reduction of disease in green house. Under field condition 
bio-priming treatment strongly reduced pea root rot $(67.8-84.5 \%)$ as against $43.2-61.4 \%$ reduction by fungicide treatment (RizulexT).

These results are similar to those reported by Lacicowa and Pjeta, 1994 and Xue, 2003, who used bio-priming as a technique of seed treatment to control many seed and soil-borne plant pathogens. Suppression of seed and soilborne pathogens of bio primed seed is related to the rate of reduction of the incidence of the seed colonization by the pathogens due to reduces seed exudation of nutrients from primed seeds, thus overcoming chilling injures (Khan, 1992); reducing the germination (We, 2000); bio agents also show a direct antagonistic ability against pathogens by eliminating pathogens that colonize seeds or roots of plants (Taylor et al., 1985).

Seed priming is an important tool to improve emergence of crops, especially under the stress conditions (Rakshit et al., 2014). Earlier works showed that combining seed priming with biocontrol agent application ultimately resulted in improvement in crops and different methods were utilized for bio-priming (Harman and Taylor 1988; Callan et al., 1991; Jensen et al., 2004; and El-Mohamedy and Abd-El-Baky, 2008). Trichoderma spp. is the most common saprophytic fungus in rhizosphere which act as mycoparasite on pathogenic fungi and on the other hand it stimulates plant growth as well (Singh et al., 2013b; Rakshit et al., 2015 and Meena et al., 2016). Trichoderma spp. is a well-known bio-control agent used in seed bio-priming (Harman and Taylor, 1988; El-Mohamedy and Abd-El-Baky, 2008; Pill et al., 2009).

\section{Vegetative growth and total fresh pods yield}

Data presented in Table (8) showed that seed treatments led to statistical increases in the vegetative growth of pea plants expressed as plant length, leaves and branches number/ plant, as well as fresh and dry weight of leaves, stems, pods and seeds and total green pods yield (ton/fed). The results revealed that the highest values of vegetative growth characters of pea plant were obtained by bio-priming seeds, seed coating and priming seeds in a descending order, respectively compared with control. These results were similar and true in the two seasons of the experiments.

These results were in agreement with those ElMohamedy and Abd-El-Baky (2008) evaluated the effect of different types of seed treatments on improvement of growth and yield quality of pea plant and reported that bio-priming with $T$. harzianum or Bacilus subtilis were the most effective treatment stimulating vegetative growth with highest values of plant height, number of leaves/ plant and branches/ plant. These treatments also significantly increased early and total fresh pods yield. Similarly, Saxena et al. (2015) reported enhancement in root and shoot lengths along with dry weight of plants with significant increase in the number of leaf in the plants treated with the Trichodemra isolate BHUF4.

It was well studied that Trichoderma spp. enhances plant growth by increasing nutrient uptake (Harman et al., 2004; Rakshit et al., 2013) along with induction of secondary root development through auxins and indoles production (Contreras-conrnejo et al., 2009, 2014 a, b). Vivek et al. (2016) showed that bio-priming enhancement in plant growth in the treated plants as compared to control. There was increase in shoot length, root length, number of leaves, shoot fresh weight, root fresh weight, shoot dry weight and root dry weight by $35.29,96.49,28.13$, $36.10,146.26,30.17$ and $77.20 \%$, respectively, as compared to the control.

\section{Effect of the interactions}

The interaction between cultivars and phosphorus fertilizer levels:

Damping-off and root rot incidence: Data presented in Table (9) clear that pea root rot disease incidence was recorded after 30 and 60 days of sowing. Results show that all phosphorus levels combined with cv. Master B reduced the incidence of root rot on pea plants until 60 days compared with other interactions during two seasons. Phosphorus fertilizer levels at 50 and 75 $\mathrm{P}_{2} \mathrm{O}_{5} /$ feddan were highly effective then 25 units/ fed in decreasing the percentage of root rot infection of MB cultivar during two seasons. The interaction between treatment of $75 \mathrm{P}_{2} \mathrm{O}_{5} /$ feddan and $\mathrm{cv}$. MB caused reduction of root rot disease incidence reach to 57.44 and $50.65 \%$ at pre emergence stage during two seasons, respectively and reduced the incidence of pea root rot by $37.65,52.72 \%$ and $52.71,48.93 \%$ at post emergency after 30 and 60 days after sowing date during two seasons, respectively. The preemergence damping off, i. e. infection and reduction (\%) and post-emergence root rot disease, i. e. incidence and reduction (\%) after 30 days of sowing during the first season did not reach a significant difference's. Meanwhile, the interaction between $75 \mathrm{P}_{2} \mathrm{O}_{5} /$ feddan and cv. $\mathrm{MB}$ cause a reduction in the incidence of pea root rot estimated by 50.68 and $52.67 \%$ after 40 and 60 days of sowing during the second season. The highly percentages of survival plants of $\mathrm{MB}$ cultivar were recorded with 50 and $75 \mathrm{P}_{2} \mathrm{O}_{5}$ unit treatments.

Many investigators reported that, increasing phosphorus rates above the level needed to grow 
the crop can increase the severity of Fusarium wilt in muskmelon (Jones et al., 1989).

\section{Vegetative growth and total fresh pods yield}

Data presented in Table (10) revealed that the highest values of vegetative growth characters of pea plants expressed as plant length, leaves and branches number/plant, as well as fresh and dry weight of leaves, stems, pods and seeds and total green pods yield (ton/fed) were obtained by the combination effect of Master B cultivar with application of mineral phosphorus fertilizer at the rate of $50 \mathrm{~kg} \mathrm{P}_{2} \mathrm{O}_{5} /$ fed compared with treatments in both seasons. Branches number/ plant during two seasons and stem fresh weight at the first season were not significant. Lower values were obtained by other interactions. The lowest values of vegetative growth were obtained by var. Litel Marvel without phosphorus. Results of green yield were with the same trend of vegetative growth. The highest green yield was obtained by Master B var. which receiving $50 \mathrm{~kg} \mathrm{P}_{2} \mathrm{O}_{5} /$ fed.

The interaction between phosphorus levels and seed treatments on pea root rot incidence

Damping-off and root rot incidence: Results in Table (11) indicated that combination between phosphorus levels and seed treatments have high effectiveness in reducing damping-off root rot disease on pea plants. Bio-priming combined with 50 and / or $75 \mathrm{P}_{2} \mathrm{O}_{5}$ /feddan were the highly effective treatments in decreasing the percent of disease infection on pea plants at pre and post emergence stages. These treatments reduced pea root rot disease at pre-emergence stage by 85.82 , $88.46 \%$ and $78.33,81.74 \%$ during two seasons, respectively and root rot at post emergence stage by $74.21,79.32 \%$ and $80.85,82.92 \%$ after 30 and 60 days of sowing, respectively during the first season and $78.42,77.41 \%$ and $81.35,80.03 \%$ after 30 and 60 days of sowing, respectively during the second season.

These results are in accordance with those observed by El-abd et al. (2013) who indicated that the combined effect of bio-priming +50 and/or $75 \mathrm{P}_{2} \mathrm{O}_{5} /$ feddan resulted the highest efficacy in reduced root rot disease caused by Fusarium spp.; Rhizoctonia solani and Sclerotium rolfsii on pea plant at both pre and post emergence stage.

Considerable disease control was achieved when seed coating treatment was combined with 50 and/or $75 \mathrm{P}_{2} \mathrm{O}_{5}$ units /feddan treatments. These treatments reduced pea root rot at pre-emergence stage by more $63.85,69.06 \%$ and $57.19,62.93 \%$ on pea plants during two seasons, respectively. The interaction between seed priming and phosphorus fertilizer levels show the least records of disease reduction compared with biopriming and seed coating treatments. The highest percent of healthy and survival pea plants were recorded with bio-priming and seed coating combined with 50 and $75 \mathrm{P}_{2} \mathrm{O}_{5}$ /feddan, i.e. 88.25, 73.50 and $92.25,79.25$ at the first season and 86.15, $71.75 \%$ and $86.50,75.25 \%$ at the second season.

Vegetative growth and total fresh pods yield: Data in Table (12) show that the highest values of vegetative growth characters of pea plants expressed as plant length, leaves and branches number/plant, as well as fresh and dry weight of leaves, stems, pods and seeds and total green pods yield (ton/fed) were obtained by the combination effect of mineral phosphorus fertilizer at the rate of $50 \mathrm{~kg} \mathrm{P}_{2} \mathrm{O}_{5} / \mathrm{fed}$. and biopriming compared with other treatments in the two seasons. Branches number/ plant and leaves fresh weight was not significant during two seasons. The lowest values of vegetative growth were obtained by without mineral phosphorus fertilizer and without seed treated.

Results of green yield were with the same trend of vegetative growth. The highest green yield was obtained by seed bio-priming treatment which receiving $50 \mathrm{~kg} \mathrm{P}_{2} \mathrm{O}_{5} /$ feddan follow up the treatment of seed bio-priming which receiving $75 \mathrm{~kg} \mathrm{P}_{2} \mathrm{O}_{5} /$ feddan at the first season. These results are in accordance with those observed by El-abd et al. (2013) who reported that inoculation of pea seed before sowing by bio-priming treatments combined with addition of mineral phosphorus resulted in the highest significant increase in vegetative growth, green pod yield and quality of pea grown in sandy soil. Phosphorus is an important nutrient that is essential for plant growth and development which is generally present in unavailable form. Many microorganisms including Trichoderma spp. produce organic acids and phosphatase that solubilize the unavailable phosphate to available phosphate that can be easily absorbed by plants. Trichoderma spp. also helps to increase the nitrogen use efficiency in plants (Rakshit et al., 2015).

\section{The interaction between cultivars and seed treatments}

Damping-off and root rot incidence: Results in Table (13) indicated that combination between cultivars of pea and seed treatments have high significant differences in reducing root rot disease on pea plants at both pre and postemergence stages. MB cultivar is superior cultivar combination with bio-priming or seed coating treatments in reducing root rot disease on pea plants compared with LM cultivar with other seed treatments. Meanwhile, combination between LM cultivar and seed priming show less effect in decreasing the disease incidence on LM cultivar of pea. 
Seeds of cv. MB combined with bio-priming treatment were the highly effective treatments in decreasing the percent of disease infection on pea plants at post -emergence stage. These treatments reduced pea root rot disease and post-emergence stage by $84.46 \%$ and $78.16 \%$ during two seasons, respectively and root rot at post emergence stages by $75.66,76.86 \%$ and $78.96,77.01 \%$ after 30 and 60 days of transplanting date, respectively during the first season and 78.42, 77.41 \% and $81.35,80.03 \%$ after 30 and 60 days of sowing, respectively during the second season. The interaction between $\mathrm{cv}$. LM and seed priming treatment show the least records of disease reduction compared with bio- priming and seed coating treatments with cv. MB. The highest percent of healthy and survival pea plants were recorded by $\mathrm{cv}$. MB combined with seed biopriming and seed coating, i.e. 90.38, 72.88 and $85.50,7.038$ during two seasons, respectively. These results are in accordance with those observed by El-Mohamedy and Abd-El-Baky, 2008 on peas.

\section{Vegetative growth and total fresh pods yield}

Data presented in Table (14) showed that the highest values of vegetative growth characters of pea plants expressed as plant length, leaves and branches number/plant, as well as fresh and dry weight of leaves, stems, pods and seeds and total green pods yield (ton/fed) were obtained by the combination effect of cv. Master B with seed biopriming treatment. The lowest values of vegetative growth characters and total pods yield were obtained by sowing of cv. Little Marvel seeds combined with without seeds treatment (control). These results were similar and true in the two seasons of the experiments. Dry weight of leaves and stems two seasons and branches numbers at the second season were not significant.

\section{The interaction between cultivars, phosphorus levels and seed treatments}

Damping-off and root rot incidence: Data presented in Tables (15 and 16) clear that pea root rot disease incidence was recorded after 30 and 60 days of sowing. Results show that all phosphorus levels reduced the incidence of root rot until 60 days on pea of $\mathrm{cv}$. MP with bio priming and seed coating treatments during two seasons. Phosphorus fertilizer levels at 50 and 75 $\mathrm{P}_{2} \mathrm{O}_{5} /$ feddan/ feddan were highly effective then $25 \mathrm{P}_{2} \mathrm{O}_{5} /$ feddan in decreasing the percentage of root rot infection of $\mathrm{cv}$. MB with bio priming during two seasons. The treatment of 75 unit of phosphorus fertilizer with bio priming treatment reduced pea root rot disease of $\mathrm{cv}$. MB at postemergence stage by $85.02 \%$ and $91.90 \%$ during two seasons, respectively and reduced the incidence of pea root rot by $82.50,82.93 \%$ and $84.38,81.58 \%$ after 30 and 60 days after sowing date during two seasons, respectively. The highly percentages of survival plants of $\mathrm{cv}$. MB were recorded with 50 and $75 \mathrm{P}_{2} \mathrm{O}_{5}$ and bio priming treatment. The infection and reduction percentage of damping off during the first season didn't reach to significant differences.

b) - Vegetative growth and total fresh pods yield: Data presented in Tables (17 and 18) show that the highest values of vegetative growth characters of pea plants expressed as plant length, leaves and branches number/ plant, as well as fresh and dry weight of leaves, stems, pods and seeds and total green pods yield (ton/fed) were obtained by the combination effect of cv. Master B, mineral phosphorus fertilizer at the rate of $50 \mathrm{~kg} \mathrm{P}_{2} \mathrm{O}_{5} /$ fed and seed bio-priming compared with other treatments in the two seasons. Branches number/ plant in the two seasons and leaves fresh weight, leaves, stems and pods dry weight in the second season were not significant. The lowest values of vegetative growth were obtained by plants cv. LM which cultivated without mineral phosphorus fertilizer and without seed treated.

\section{CONCLUSION}

It can be concluded from the present investigation that pea growers may use poor quality seeds with high incidence of seed borne fungi. Bio-priming of seeds is the modern technique for seed quality enhancement and can be used in integrated management of seed borne diseases. Before recommendation for field application, it is necessary to standardize hours of soaking for bio-priming. It was found that four hour soaking of seeds in water or in suspension of bio-control agent was the most effective in seed quality parameters. Recommend by using pea seeds of cv. Master B in cultivation and using bioprimed seeds with bio-control agents like $T$. harzianum or T. viride or T. asperellum should be utilized for managing seed borne pathogens and fertilizing pea plants by adding mineral phosphorus fertilizer at the rate of 50 or $75 \mathrm{~kg}$ $\mathrm{P}_{2} \mathrm{O}_{5} /$ feddan for improving pods yield and quality seeds. 
Table 3. Effect of cultivars on post-emergence damping off incidence percentage, root rot disease incidence percentage and survival plans of pea plants during two seasons 2014/2015 and 2015/2016.

\begin{tabular}{|c|c|c|c|c|}
\hline \multirow[b]{2}{*}{ Cultivars } & \multirow[t]{2}{*}{ Post-emergence damping off (\%) } & \multicolumn{2}{|c|}{ Root rot disease incidence $(\%)$} & \multirow{2}{*}{$\begin{array}{c}\text { Survival } \\
\text { Plant } \\
(\%) \\
\end{array}$} \\
\hline & & $\begin{array}{l}\text { After } \\
30 \text { day }\end{array}$ & $\begin{array}{l}\text { After } \\
60 \text { day }\end{array}$ & \\
\hline & \multicolumn{4}{|c|}{ First season $(2014 / 2015)$} \\
\hline Little Marvel & 11.56 & 14.38 & 15.04 & 59.29 \\
\hline Master B & 9.91 & 11.91 & 9.47 & 63.38 \\
\hline L.S.D at 0.05 & 0.02 & 0.06 & 0.02 & 0.02 \\
\hline & \multicolumn{4}{|c|}{ Second season $(2015 / 2016)$} \\
\hline Little Marvel & 14.14 & 14.80 & 15.01 & 56.10 \\
\hline Master B & 11.56 & 11.89 & 10.80 & 64.72 \\
\hline L.S.D at 0.05 & 0.02 & 0.06 & 0.02 & 0.03 \\
\hline
\end{tabular}

Table 4. Effect of cultivars on vegetative growth and total fresh pods yield of pea during two seasons (2014/2015 and 2015/2016).

\begin{tabular}{|c|c|c|c|c|c|c|c|c|c|c|c|c|}
\hline \multirow[t]{2}{*}{ Cultivars } & \multirow{2}{*}{$\begin{array}{l}\text { Plant } \\
\text { Length } \\
\text { (cm) }\end{array}$} & \multirow{2}{*}{$\begin{array}{l}\text { Leaves } \\
\text { No./ } \\
\text { plant }\end{array}$} & \multirow{2}{*}{$\begin{array}{l}\text { Branches } \\
\text { No./ } \\
\text { plant }\end{array}$} & \multicolumn{4}{|c|}{ Fresh weight (g/ plant) } & \multicolumn{4}{|c|}{ Dry weight (g/ plant) } & \multirow{2}{*}{$\begin{array}{l}\text { Total } \\
\text { pods yield } \\
\text { (ton/ fed.) }\end{array}$} \\
\hline & & & & Leaves & Stems & Pods & Seeds & Leaves & Stems & Pods & Seeds & \\
\hline & \multicolumn{12}{|c|}{ First season $(2014 / 2015)$} \\
\hline Little Marvel & 63.94 & 22.56 & 2.17 & 18.14 & 7.41 & 43.73 & 21.96 & 7.94 & 3.15 & 4.98 & 6.20 & 4.414 \\
\hline Master B & 64.90 & 25.88 & 2.71 & 24.02 & 6.99 & 63.13 & 37.00 & 9.32 & 3.37 & 5.98 & 11.08 & 6.728 \\
\hline L.S.D at 0.05 & N.S. & 0.94 & N.S. & 0.28 & N.S. & 1.06 & 0.92 & 0.32 & N.S. & 0.13 & 0.11 & 0.090 \\
\hline & \multicolumn{12}{|c|}{ Second season $(2015 / 2016)$} \\
\hline Little Marvel & 61.67 & 19.04 & 1.98 & 17.87 & 7.21 & 43.93 & 22.17 & 6.46 & 1.96 & 4.13 & 5.30 & 4.442 \\
\hline Master B & 62.06 & 21.94 & 2.38 & 20.47 & 7.44 & 53.40 & 31.97 & 7.85 & 2.06 & 4.94 & 7.53 & 5.737 \\
\hline L.S.D at 0.05 & N.S. & 0.68 & N.S. & 0.85 & N.S. & 0.41 & 0.69 & 0.16 & N.S. & 0.07 & 0.10 & 0.041 \\
\hline
\end{tabular}


Table 5. Effect of phosphorus levels on post-emergence damping off incidence percentage, root rot disease incidence percentage and survival plans of pea plants during two seasons (2014/2015 and 2015/2016).

\begin{tabular}{|c|c|c|c|c|}
\hline \multirow{2}{*}{$\begin{array}{l}\text { Phosphorus Levels } \\
\left(\mathrm{P}_{2} \mathrm{O}_{5}\right) / \text { fed. }\end{array}$} & \multirow{2}{*}{$\begin{array}{l}\text { Post-emergence damping off (\%) } \\
\text { Infection (\%) }\end{array}$} & \multicolumn{2}{|c|}{ Root rot disease incidence $(\%)$} & \multirow{2}{*}{$\begin{array}{l}\text { Survival } \\
\text { Plant }(\%)\end{array}$} \\
\hline & & After 30 day & After 60 day & \\
\hline & First season $(2014 / 2015)$ & & & \\
\hline 0 & 10.28 & 12.39 & 11.45 & 51.04 \\
\hline 25 & 9.25 & 11.19 & 10.44 & 54.47 \\
\hline 50 & 7.88 & 10.23 & 9.38 & 57.91 \\
\hline 75 & 6.94 & 9.06 & 8.56 & 61.72 \\
\hline \multirow{2}{*}{ L.S.D at 0.05} & 0.23 & 0.20 & 0.02 & 0.02 \\
\hline & Second season $(2015 / 2016)$ & & & \\
\hline 0 & 12.26 & 13.27 & 12.51 & 49.08 \\
\hline 25 & 11.19 & 11.41 & 11.47 & 53.00 \\
\hline 50 & 9.63 & 9.59 & 9.44 & 58.38 \\
\hline 75 & 8.81 & 9.05 & 8.60 & 60.53 \\
\hline L.S.D at 0.05 & 0.02 & 0.05 & 0.02 & 0.04 \\
\hline
\end{tabular}

Table 6. Effect of phosphorus levels on vegetative growth and total fresh pods yield of pea during two seasons (2014/2015 and 2015/2016).

\begin{tabular}{|c|c|c|c|c|c|c|c|c|c|c|c|c|c|}
\hline \multirow{2}{*}{\multicolumn{2}{|c|}{ P levels }} & \multirow{2}{*}{$\begin{array}{l}\text { Plant } \\
\text { Length } \\
(\mathrm{cm})\end{array}$} & \multirow{2}{*}{$\begin{array}{l}\text { Leaves } \\
\text { No./ } \\
\text { plant }\end{array}$} & \multirow{2}{*}{$\begin{array}{l}\text { Branches } \\
\text { No./ } \\
\text { plant }\end{array}$} & \multicolumn{4}{|c|}{ Fresh weight (g/ plant) } & \multicolumn{4}{|c|}{ Dry weight (g/ plant) } & \multirow{2}{*}{$\begin{array}{l}\text { Total } \\
\text { pods yield } \\
\text { (ton/fed.) }\end{array}$} \\
\hline & & & & & Leaves & Stems & Pods & Seeds & Leaves & Stems & Pods & Seeds & \\
\hline & & \multicolumn{12}{|c|}{ First season $(2014 / 2015)$} \\
\hline 0 & & 52.02 & 18.60 & 1.58 & 14.19 & 4.29 & 37.14 & 21.72 & 5.95 & 2.23 & 3.99 & 6.48 & 3.956 \\
\hline 25 & & 55.94 & 22.58 & 2.02 & 19.75 & 5.00 & 48.34 & 26.08 & 7.41 & 2.88 & 4.62 & 8.35 & 5.001 \\
\hline 50 & & 61.33 & 25.10 & 2.77 & 25.64 & 9.11 & 63.40 & 32.74 & 9.65 & 3.07 & 6.08 & 9.61 & 6.461 \\
\hline \multirow[t]{3}{*}{75} & & 59.77 & 23.27 & 2.63 & 19.11 & 8.58 & 49.01 & 27.61 & 9.49 & 4.09 & 5.95 & 7.65 & 5.149 \\
\hline & L.S.D at 0.05 & 1.06 & 1.08 & 0.18 & 0.83 & 0.40 & 1.15 & 0.54 & 0.37 & 0.19 & 0.26 & 0.20 & 0.097 \\
\hline & & \multicolumn{12}{|c|}{ Second season $(2015 / 2016)$} \\
\hline 0 & & 51.38 & 15.10 & 1.71 & 15.52 & 5.79 & 36.21 & 20.35 & 5.33 & 1.32 & 3.45 & 4.73 & 3.80 \\
\hline 25 & & 55.85 & 18.19 & 1.79 & 17.59 & 6.64 & 43.53 & 23.84 & 6.15 & 1.84 & 3.95 & 6.27 & 4.53 \\
\hline 50 & & 58.27 & 21.13 & 2.46 & 19.86 & 7.43 & 49.43 & 28.26 & 7.40 & 2.07 & 4.29 & 7.10 & 5.22 \\
\hline 75 & & 54.04 & 19.29 & 2.06 & 17.25 & 6.76 & 46.08 & 24.97 & 6.85 & 2.05 & 4.58 & 5.41 & 4.77 \\
\hline & L.S.D at 0.05 & 0.50 & 0.37 & 0.16 & 1.41 & 0.18 & 1.06 & 0.71 & 0.13 & 0.10 & 0.10 & 0.23 & 0.094 \\
\hline
\end{tabular}


Table 7. Effect of seed treatments on post-emergence damping off incidence percentage, root rot disease incidence percentage and survival plans of pea plants during two seasons $(2014 / 2015$ and $2015 / 2016)$

\begin{tabular}{|c|c|c|c|c|}
\hline \multirow{2}{*}{$\begin{array}{c}\text { Seed } \\
\text { treatments }\end{array}$} & \multirow{2}{*}{$\begin{array}{l}\text { Post-emergence damping off }(\%) \\
\text { Infection } \\
(\%)\end{array}$} & \multicolumn{2}{|c|}{ Root rot disease incidence (\%) } & \multirow{2}{*}{$\begin{array}{l}\text { Survival } \\
\text { Plant } \\
(\%)\end{array}$} \\
\hline & & $\begin{array}{l}\text { After } \\
30 \text { day }\end{array}$ & $\begin{array}{l}\text { After } \\
60 \text { day }\end{array}$ & \\
\hline & & \multicolumn{2}{|c|}{ First season $(2014 / 2015)$} & \\
\hline Control & 17.19 & 19.42 & 18.40 & 40.40 \\
\hline Bio-priming & 3.63 & 6.09 & 5.00 & 86.13 \\
\hline Priming & 14.56 & 17.67 & 17.13 & 47.00 \\
\hline Seed coating & 7.56 & 9.40 & 8.50 & 71.81 \\
\hline \multirow[t]{2}{*}{ L.S.D at 0.05} & 0.24 & 0.15 & 0.02 & 0.02 \\
\hline & & \multicolumn{2}{|c|}{ Second season $(2015 / 2016)$} & \\
\hline Control & 19.02 & 20.10 & 19.21 & 41.29 \\
\hline Bio-priming & 5.75 & 5.94 & 5.31 & 82.48 \\
\hline Priming & 17.00 & 17.02 & 16.35 & 49.06 \\
\hline Seed coating & 9.63 & 10.31 & 10.75 & 68.81 \\
\hline L.S.D at 0.05 & 0.02 & 0.06 & 0.02 & 0.04 \\
\hline
\end{tabular}

Table 8. Effect of seed treatments on vegetative growth and total pods yield of pea during two seasons (2014/2015 and 2015/2016).

\begin{tabular}{|c|c|c|c|c|c|c|c|c|c|c|c|c|}
\hline \multirow{2}{*}{$\begin{array}{l}\text { Seed } \\
\text { treatments }\end{array}$} & \multirow{2}{*}{$\begin{array}{l}\text { Plant } \\
\text { Length } \\
(\mathrm{cm})\end{array}$} & \multirow{2}{*}{$\begin{array}{l}\text { Leaves } \\
\text { No./plant }\end{array}$} & \multirow{2}{*}{$\begin{array}{l}\text { Branches } \\
\text { No./plant }\end{array}$} & \multicolumn{4}{|c|}{ Fresh weight (g/ plant) } & \multicolumn{4}{|c|}{ Dry weight (g/ plant) } & \multirow{2}{*}{$\begin{array}{l}\text { Total } \\
\text { pods yielc } \\
\text { (ton/ fed.) }\end{array}$} \\
\hline & & & & Leaves & Stems & Pods & Seeds & Leaves & Stems & Pods & Seeds & \\
\hline & \multicolumn{12}{|c|}{ First season $(2014 / 2015)$} \\
\hline Control & 57.21 & 14.63 & 1.50 & 11.24 & 3.63 & 31.63 & 19.52 & 4.03 & 1.55 & 2.54 & 4.97 & 3.438 \\
\hline Bio-priming & 70.83 & 35.00 & 3.46 & 31.26 & 11.40 & 80.64 & 40.08 & 12.82 & 5.51 & 8.35 & 12.37 & 8.112 \\
\hline Priming & 63.04 & 19.21 & 2.17 & 16.42 & 5.49 & 45.16 & 27.74 & 7.00 & 2.27 & 4.80 & 7.72 & 4.899 \\
\hline Seed coating & 66.58 & 28.04 & 2.63 & 25.39 & 8.28 & 56.28 & 30.58 & 10.66 & 3.71 & 6.22 & 9.52 & 5.837 \\
\hline L.S.D at 0.05 & 1.09 & 1.21 & 0.22 & 1.26 & 0.41 & 1.57 & 0.79 & 0.38 & 0.28 & 0.43 & 0.24 & 0.113 \\
\hline & \multicolumn{12}{|c|}{ Second season $(2015 / 2016)$} \\
\hline Control & 55.83 & 16.50 & 1.38 & 12.92 & 5.37 & 38.84 & 21.72 & 5.76 & 1.52 & 3.70 & 4.29 & 4.069 \\
\hline Bio-priming & 68.17 & 25.08 & 2.96 & 24.90 & 9.10 & 58.77 & 34.68 & 8.25 & 2.38 & 5.30 & 9.74 & 6.280 \\
\hline Priming & 59.96 & 19.25 & 2.00 & 17.95 & 6.43 & 45.48 & 24.60 & 6.90 & 2.00 & 4.45 & 5.14 & 4.709 \\
\hline Seed coating & 63.50 & 21.13 & 2.38 & 20.91 & 8.41 & 51.59 & 27.28 & 7.69 & 2.13 & 4.69 & 6.49 & 5.300 \\
\hline L.S.D at 0.05 & 0.74 & 0.50 & 0.21 & 1.90 & 0.22 & 1.16 & 1.05 & 0.21 & 0.14 & 0.14 & 0.22 & 0.107 \\
\hline
\end{tabular}


Table 9. Effect of the interaction between cultivars and phosphors levels on post-emergence damping off incidence percentage, root rot disease incidence percentage and survival plan percentage of pea during two seasons (2014/2015 and 2015/2016).

\begin{tabular}{|c|c|c|c|c|c|}
\hline \multirow[t]{2}{*}{ Cultivars } & \multirow{2}{*}{$\begin{array}{l}\text { Phosphors } \\
\text { levels }\end{array}$} & Post-emergence damping off (\%) & \multicolumn{2}{|c|}{ Root rot disease incidence (\%) } & \multirow{2}{*}{$\begin{array}{rr} & \text { Survival } \\
(\%) & \text { Plant } \\
\end{array}$} \\
\hline & & $\begin{array}{l}\text { Infection } \\
\end{array}$ & $\begin{array}{l}\text { After } \\
30 \text { day }\end{array}$ & $\begin{array}{l}\text { After } \\
60 \text { day }\end{array}$ & \\
\hline \multirow{5}{*}{ Little Marvel } & & First season (2014/2015) & & & \\
\hline & 0 & 13.50 & 16.44 & 16.92 & 53.42 \\
\hline & 25 & 12.00 & 15.13 & 15.50 & 57.75 \\
\hline & 50 & 10.88 & 13.71 & 14.50 & 61.00 \\
\hline & 75 & 9.88 & 12.25 & 13.25 & 65.00 \\
\hline \multirow{4}{*}{ Master B } & 0 & 11.88 & 13.63 & 11.00 & 57.50 \\
\hline & 25 & 10.88 & 12.25 & 10.13 & 60.63 \\
\hline & 50 & 9.00 & 11.50 & 8.75 & 65.38 \\
\hline & 75 & 7.88 & 10.25 & 8.00 & 70.00 \\
\hline L.S.D at 0.05 & & N.S. & N.S. & 0.03 & 0.03 \\
\hline \multirow{5}{*}{ Little Marvel } & & Second season (2015/2016) & & & \\
\hline & 0 & 16.42 & 17.83 & 17.29 & 48.71 \\
\hline & 25 & 15.13 & 15.75 & 16.25 & 52.88 \\
\hline & 50 & 12.88 & 13.13 & 13.63 & 60.33 \\
\hline & 75 & 12.13 & 12.50 & 12.88 & 62.50 \\
\hline \multirow{4}{*}{ Master B } & 0 & 13.50 & 14.38 & 13.00 & 58.13 \\
\hline & 25 & 12.00 & 12.38 & 11.63 & 63.00 \\
\hline & 50 & 10.88 & 10.75 & 9.75 & 67.63 \\
\hline & 75 & 9.88 & 10.04 & 8.83 & 70.13 \\
\hline L.S.D at 0.05 & & 0.03 & 0.09 & 0.03 & 0.06 \\
\hline
\end{tabular}


Table 10. Effect of the interaction between cultivars with phosphorus levels on vegetative growth and total fresh pods yield of pea during two seasons (2014/2015 and 2015/2016)

\begin{tabular}{|c|c|c|c|c|c|c|c|c|c|c|c|c|c|}
\hline \multirow[t]{2}{*}{ Cultivars } & \multirow{2}{*}{$\begin{array}{l}\mathrm{P} \\
\text { levels }\end{array}$} & \multirow{2}{*}{$\begin{array}{l}\text { Plant } \\
\text { Length } \\
\text { (cm) }\end{array}$} & \multirow{2}{*}{$\begin{array}{l}\text { Leaves } \\
\text { No./ } \\
\text { plant }\end{array}$} & \multirow{2}{*}{$\begin{array}{l}\text { Branches } \\
\text { No./ } \\
\text { plant }\end{array}$} & \multicolumn{4}{|c|}{ Fresh weight (g/ plant) } & \multicolumn{4}{|c|}{ Dry weight (g/ plant) } & \multirow{2}{*}{$\begin{array}{l}\text { Total pods yield } \\
\text { (ton/ fed.) }\end{array}$} \\
\hline & & & & & Leaves & Stems & Pods & Seeds & Leaves & Stems & Pods & Seeds & \\
\hline $\begin{array}{l}\text { Little } \\
\text { Marvel }\end{array}$ & $\begin{array}{l}0 \\
25 \\
50 \\
75 \\
\end{array}$ & $\begin{array}{l}\text { First sea } \\
56.42 \\
61.33 \\
68.83 \\
69.17\end{array}$ & $\begin{array}{l}14 / 2015) \\
14.75 \\
17.83 \\
30.08 \\
27.58\end{array}$ & $\begin{array}{l}1.50 \\
1.67 \\
2.83 \\
2.67\end{array}$ & $\begin{array}{l}11.48 \\
15.81 \\
24.96 \\
20.32\end{array}$ & $\begin{array}{l}3.58 \\
4.44 \\
11.37 \\
10.26\end{array}$ & $\begin{array}{l}30.41 \\
34.75 \\
60.72 \\
49.05\end{array}$ & $\begin{array}{l}16.24 \\
16.39 \\
23.61 \\
31.60\end{array}$ & $\begin{array}{l}4.58 \\
5.70 \\
10.54 \\
10.92\end{array}$ & $\begin{array}{l}1.84 \\
2.00 \\
3.31 \\
5.47\end{array}$ & $\begin{array}{l}3.05 \\
3.75 \\
6.42 \\
6.69\end{array}$ & $\begin{array}{l}4.87 \\
6.06 \\
6.48 \\
7.40\end{array}$ & $\begin{array}{l}3.135 \\
3.437 \\
5.667 \\
5.419\end{array}$ \\
\hline & 0 & 59.92 & 25.17 & 1.92 & 18.51 & 5.66 & 48.38 & 30.42 & 7.83 & 2.92 & 5.49 & 9.19 & 5.296 \\
\hline Master & 25 & 64.08 & 31.17 & 2.75 & 26.26 & 6.24 & 68.31 & 40.09 & 10.26 & 4.16 & 5.92 & 11.80 & 7.284 \\
\hline B & 50 & 69.92 & 24.50 & 3.17 & 30.42 & 7.93 & 78.26 & 47.97 & 10.10 & 3.27 & 6.47 & 13.99 & 8.482 \\
\hline & 75 & 65.67 & 22.67 & 3.00 & 20.86 & 8.11 & 57.55 & 29.51 & 9.11 & 3.12 & 6.03 & 9.36 & 5.850 \\
\hline & L.S.D at ${ }_{0.05}$ & 1.83 & 1.87 & N.S. & 1.43 & 0.70 & 2.00 & 0.93 & 0.63 & 0.32 & 0.45 & 0.34 & 0.167 \\
\hline $\begin{array}{l}\text { Little } \\
\text { Marvel }\end{array}$ & $\begin{array}{l}0 \\
25 \\
50 \\
75\end{array}$ & $\begin{array}{l}\text { Second } \\
56.33 \\
63.50 \\
65.25 \\
61.58 \\
\end{array}$ & $\begin{array}{l}2015 / 20 \\
15.25 \\
19.83 \\
21.75 \\
19.33 \\
\end{array}$ & $\begin{array}{l}1.75 \\
1.83 \\
2.25 \\
2.08 \\
-\end{array}$ & $\begin{array}{l}15.48 \\
19.29 \\
19.20 \\
17.52 \\
\end{array}$ & $\begin{array}{l}6.48 \\
6.96 \\
8.13 \\
7.27 \\
\end{array}$ & $\begin{array}{l}34.58 \\
44.50 \\
49.33 \\
47.32 \\
\end{array}$ & $\begin{array}{l}16.90 \\
22.80 \\
24.56 \\
24.41 \\
\end{array}$ & $\begin{array}{l}4.58 \\
6.67 \\
7.19 \\
7.38 \\
\end{array}$ & $\begin{array}{l}1.51 \\
2.06 \\
2.15 \\
2.13 \\
\end{array}$ & $\begin{array}{l}3.46 \\
3.88 \\
4.43 \\
4.75 \\
\end{array}$ & $\begin{array}{l}3.62 \\
5.38 \\
6.20 \\
6.01 \\
\end{array}$ & $\begin{array}{l}3.460 \\
4.523 \\
4.966 \\
4.820 \\
\end{array}$ \\
\hline & 0 & 58.58 & 18.17 & 1.92 & 17.93 & 6.08 & 43.80 & 27.66 & 6.83 & 1.42 & 4.08 & 6.62 & 4.802 \\
\hline $\begin{array}{l}\text { Master } \\
\text { B }\end{array}$ & $\begin{array}{l}25 \\
50 \\
75 \\
\text { L.S.D at } \\
0.05\end{array}$ & $\begin{array}{l}62.83 \\
66.50 \\
60.33 \\
0.86\end{array}$ & $\begin{array}{l}20.92 \\
25.33 \\
23.33 \\
0.64\end{array}$ & $\begin{array}{l}2.08 \\
3.08 \\
2.42 \\
\text { N.S. }\end{array}$ & $\begin{array}{l}19.44 \\
23.96 \\
20.54 \\
\text { N.S. }\end{array}$ & $\begin{array}{l}7.78 \\
8.22 \\
7.68 \\
\text { N.S. }\end{array}$ & $\begin{array}{l}52.90 \\
60.35 \\
56.56 \\
\text { N.S. }\end{array}$ & $\begin{array}{l}29.91 \\
38.79 \\
31.52 \\
1.23\end{array}$ & $\begin{array}{l}7.15 \\
9.43 \\
7.98 \\
0.23\end{array}$ & $\begin{array}{l}1.99 \\
2.49 \\
2.33 \\
\text { N.S. }\end{array}$ & $\begin{array}{l}4.90 \\
5.20 \\
5.57 \\
\text { N.S. }\end{array}$ & $\begin{array}{l}8.20 \\
9.45 \\
5.83 \\
0.40\end{array}$ & $\begin{array}{l}5.565 \\
6.663 \\
5.919 \\
0.162\end{array}$ \\
\hline
\end{tabular}


Table 11. Effect of interaction between phosphorus levels and seed treatments on post-emergence damping off incidence percentage, root rot disease incidence percentage and survival plans percentage of pea during two seasons (2014/2015 and 2015/2016).

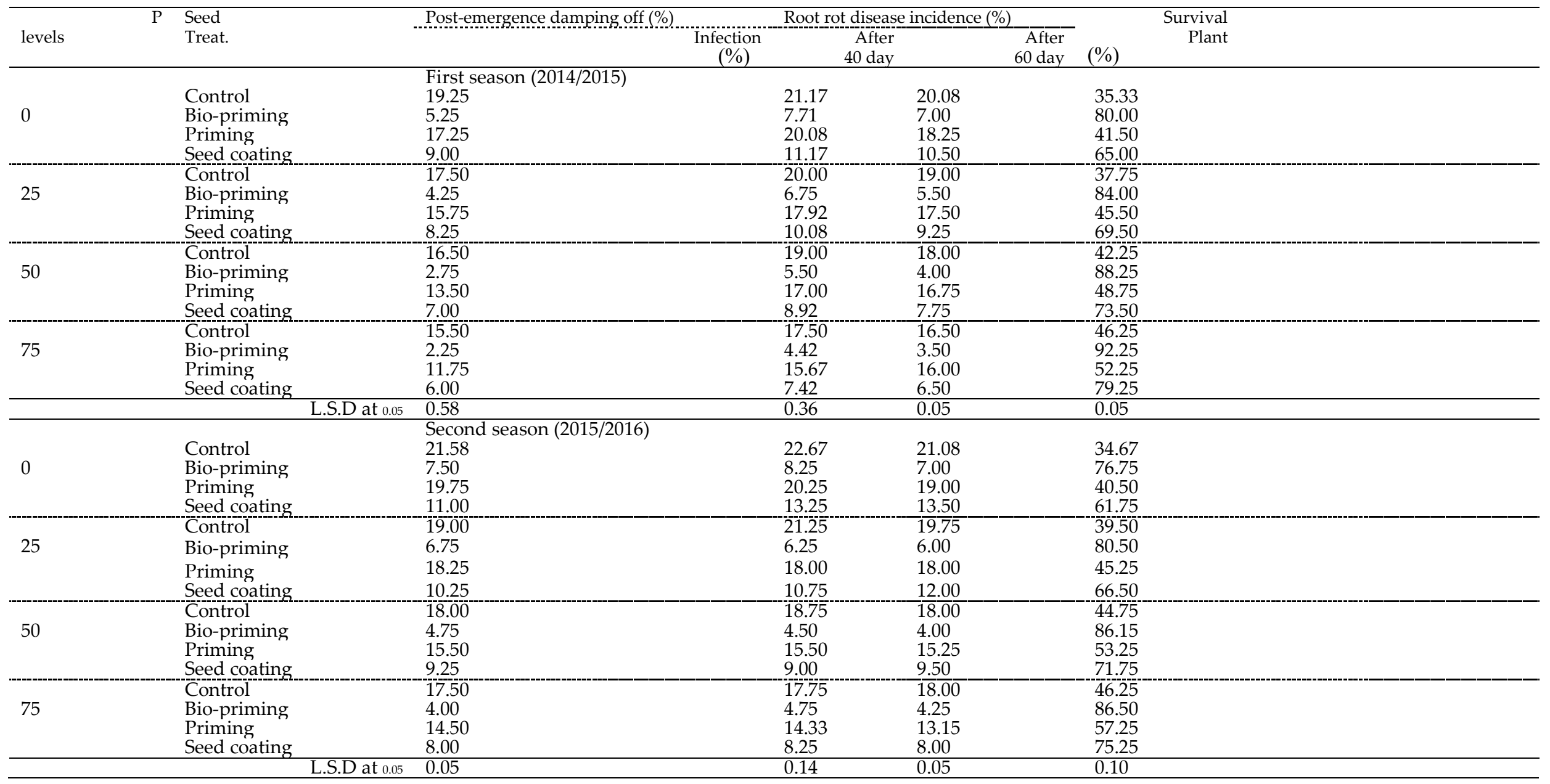


Table 12. Effect of the interaction between phosphorus levels and seed treatments on vegetative growth and total pods yield of pea during two seasons (2014/2015 and 2015/2016)

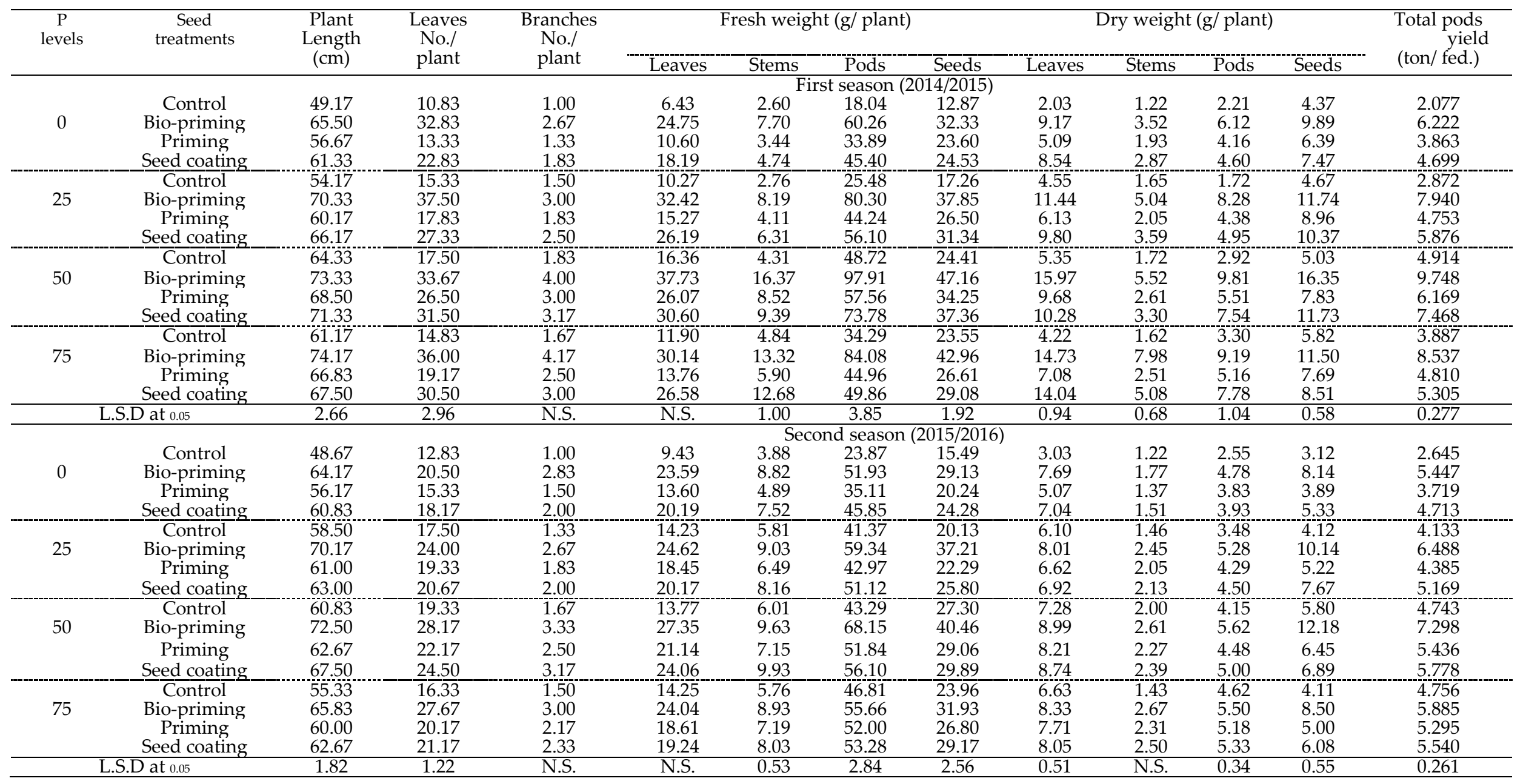


Table 13. Effect of the interaction between cultivars and different seed treatments on post-emergence damping off incidence percentage, root rot disease incidence percentage and survival plans percentage of pea during two seasons (2014/2015 and 2015/2016)

\begin{tabular}{|c|c|c|c|c|c|}
\hline \multirow[t]{2}{*}{ Cultivars } & \multirow[t]{2}{*}{ Seed treatments } & \multirow{2}{*}{$\begin{array}{l}\text { Post-emergence damping-off (\%) } \\
\text { Infection } \\
(\%)\end{array}$} & \multicolumn{2}{|c|}{ Root rot incidence (\%) } & \multirow{2}{*}{$\begin{array}{l}\text { Survival } \\
\text { Plant } \\
(\%)\end{array}$} \\
\hline & & & $\begin{array}{l}\text { After } \\
30 \text { day }\end{array}$ & $\begin{array}{l}\text { After } \\
60 \text { day }\end{array}$ & \\
\hline \multirow{5}{*}{ Little Marvel } & & First Season 2014/2015 & & & \\
\hline & Control & 17.63 & 20.71 & 22.42 & 39.04 \\
\hline & Bio-Priming & 4.38 & 7.31 & 6.63 & 81.88 \\
\hline & Priming & 15.50 & 18.71 & 20.63 & 45.50 \\
\hline & Seed Coating & 8.75 & 10.79 & 10.50 & 70.75 \\
\hline \multirow{4}{*}{ Master B } & Control & 16.75 & 18.13 & 14.38 & 41.75 \\
\hline & Bio-Priming & 2.88 & 4.88 & 3.38 & 90.38 \\
\hline & Priming & 13.63 & 16.63 & 13.63 & 48.50 \\
\hline & Seed Coating & 6.38 & 8.00 & 6.50 & 72.88 \\
\hline L.S.D at 0.05 & & 0.33 & 0.21 & 0.03 & 0.03 \\
\hline \multirow{5}{*}{ Little Marvel } & & Second Season 2014/2015 & & & \\
\hline & Control & 20.42 & 21.83 & 21.29 & 36.71 \\
\hline & Bio-priming & 7.13 & 7.13 & 6.25 & 79.45 \\
\hline & Priming & 18.50 & 18.50 & 19.00 & 44.00 \\
\hline & Seed Coating & 10.50 & 11.75 & 13.50 & 64.25 \\
\hline \multirow{4}{*}{ Master B } & Control & 17.63 & 18.38 & 17.13 & 45.88 \\
\hline & Bio-priming & 4.38 & 4.75 & 4.38 & 85.50 \\
\hline & Priming 0 & 15.50 & 15.54 & 13.70 & 54.13 \\
\hline & Seed Coating & 8.75 & 8.88 & 8.00 & 73.38 \\
\hline L.S.D at 0.05 & & 0.03 & 0.08 & 0.03 & 0.06 \\
\hline
\end{tabular}


Table 14. Effect of the interaction between cultivars and seed treatments on vegetative growth and total pods yield of pea during two seasons (2014/2015 and 2015/2016).

\begin{tabular}{|c|c|c|c|c|c|c|c|c|c|c|c|c|c|}
\hline \multirow[t]{2}{*}{ Cultivars } & \multirow{2}{*}{$\begin{array}{l}\text { Seed } \\
\text { treatments }\end{array}$} & \multirow{2}{*}{$\begin{array}{l}\text { Plant } \\
\text { Length } \\
(\mathrm{cm})\end{array}$} & \multirow{2}{*}{$\begin{array}{l}\text { Leaves } \\
\text { No./ } \\
\text { plant }\end{array}$} & \multirow{2}{*}{$\begin{array}{l}\text { Branches } \\
\text { No./ } \\
\text { plant }\end{array}$} & \multicolumn{4}{|c|}{ Fresh weight (g/plant) } & \multicolumn{4}{|c|}{ Dry weight (g/ plant) } & \multirow{2}{*}{$\begin{array}{l}\text { Total pods yield } \\
\text { (ton/ fed.) }\end{array}$} \\
\hline & & & & & Leaves & Stems & Pods & Seeds & Leaves & Stems & Pods & Seeds & \\
\hline & & First sea & $2014 / 201$ & & & & & & & & & & \\
\hline & Control & 56.50 & 12.58 & 1.25 & 9.85 & 3.72 & 24.68 & 11.04 & 3.73 & 1.45 & 2.40 & 2.39 & 2.400 \\
\hline Little & Bio-priming & 71.17 & 32.50 & 2.92 & 27.32 & 11.88 & 64.03 & 32.97 & 12.05 & 5.68 & 7.16 & 9.93 & 6.518 \\
\hline \multirow{2}{*}{ Marvel } & Priming & 61.25 & 20.08 & 2.08 & 14.81 & 5.99 & 35.71 & 20.84 & 6.10 & 2.06 & 4.41 & 5.79 & 3.800 \\
\hline & Seed coating & 66.83 & 25.08 & 2.42 & 20.59 & 8.05 & 50.51 & 22.99 & 9.86 & 3.44 & 5.93 & 6.71 & 4.939 \\
\hline \multirow{4}{*}{$\begin{array}{c}\text { Master } \\
\mathrm{B}\end{array}$} & Control & 57.92 & 16.67 & 1.75 & 12.63 & 3.53 & 38.59 & 28.01 & 4.34 & 1.66 & 2.67 & 7.55 & 4.475 \\
\hline & Bio-priming & 70.50 & 37.50 & 4.00 & 35.20 & 10.91 & 97.24 & 47.18 & 13.60 & 5.35 & 9.54 & 14.81 & 9.705 \\
\hline & Priming & 64.83 & 18.33 & 2.25 & 18.04 & 5.00 & 54.62 & 34.64 & 7.89 & 2.49 & 5.20 & 9.65 & 5.998 \\
\hline & Seed coating & 66.33 & 31.00 & 2.83 & 30.19 & 8.51 & 62.06 & 38.17 & 11.46 & 3.98 & 6.50 & 12.32 & 6.735 \\
\hline \multicolumn{2}{|r|}{ L.S.D at 0.05} & 1.54 & 1.71 & 0.30 & 1.78 & N.S. & 2.22 & 1.11 & N.S. & N.S. & 0.60 & 0.34 & 0.160 \\
\hline \multirow{5}{*}{$\begin{array}{l}\text { Little } \\
\text { Marvel }\end{array}$} & & \multicolumn{3}{|c|}{ Second season $(2015 / 2016)$} & & & & & & & & & \\
\hline & Control & 55.00 & 15.75 & 1.08 & 11.05 & 5.40 & 32.33 & 16.30 & 4.95 & 1.36 & 3.11 & 3.00 & 3.268 \\
\hline & Bio-priming & 70.00 & 23.50 & 2.67 & 23.98 & 8.64 & 57.47 & 33.37 & 7.59 & 2.42 & 5.05 & 8.26 & 6.105 \\
\hline & Priming & 58.42 & 18.08 & 1.92 & 17.23 & 6.52 & 37.51 & 18.50 & 6.17 & 1.93 & 4.07 & 4.17 & 3.763 \\
\hline & Seed coating & 63.25 & 18.83 & 2.25 & 19.24 & 8.28 & 48.42 & 20.51 & 7.12 & 2.13 & 4.29 & 5.79 & 4.632 \\
\hline \multirow{5}{*}{$\begin{array}{l}\text { Master } \\
\text { B }\end{array}$} & Control & 56.67 & 17.25 & 1.67 & 14.79 & 5.33 & 45.34 & 27.14 & 6.57 & 1.69 & 4.29 & 5.58 & 4.871 \\
\hline & Bio-priming & 66.33 & 26.67 & 3.25 & 25.82 & 9.56 & 60.06 & 35.99 & 8.92 & 2.33 & 5.55 & 11.22 & 6.455 \\
\hline & Priming & 61.50 & 20.42 & 2.08 & 18.68 & 6.34 & 53.45 & 30.69 & 7.64 & 2.07 & 4.82 & 6.11 & 5.655 \\
\hline & Seed coating & 63.75 & 23.42 & 2.50 & 22.59 & 8.54 & 54.76 & 34.06 & 8.25 & 2.14 & 5.09 & 7.20 & 5.968 \\
\hline & L.S.D at 0.05 & 1.05 & 0.70 & N.S. & N.S. & 0.31 & 1.64 & 1.48 & N.S. & N.S. & 0.20 & 0.32 & 0.151 \\
\hline
\end{tabular}




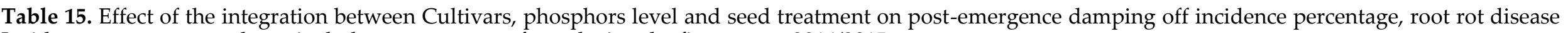
Incidence percentage and survival plans percentage of pea during the first season 2014/2015.

\begin{tabular}{|c|c|c|c|c|c|c|}
\hline \multirow[t]{2}{*}{ Cultivars } & \multirow{2}{*}{$\begin{array}{c}\text { Phosphors } \\
\text { Level }\end{array}$} & \multirow[t]{2}{*}{ Seed treatments } & \multirow{2}{*}{$\begin{array}{l}\text { Post-emergence damping-off (\%) } \\
\text { Infection } \\
(\%)\end{array}$} & \multicolumn{2}{|c|}{ Root rot incidence (\%) } & \multirow{2}{*}{$\begin{array}{l}\text { Survival } \\
\text { Plant } \\
(\%)\end{array}$} \\
\hline & & & & $\begin{array}{l}\text { After } \\
40 \text { day }\end{array}$ & $\begin{array}{l}\text { After } \\
60 \text { day }\end{array}$ & \\
\hline \multirow{16}{*}{ Little Marvel } & \multirow{4}{*}{0} & Control & 20.00 & 22.33 & 24.17 & 34.17 \\
\hline & & Bio-Priming & 6.00 & 8.92 & 9.00 & 75.50 \\
\hline & & Priming & 18.00 & 22.17 & 22.00 & 40.00 \\
\hline & & Seed Coating & 10.00 & 12.33 & 12.50 & 64.00 \\
\hline & \multirow{4}{*}{25} & Control & 17.50 & 21.00 & 23.00 & 37.00 \\
\hline & & Bio-Priming & 5.00 & 8.50 & 7.50 & 80.00 \\
\hline & & Priming & 16.50 & 19.33 & 20.50 & 45.00 \\
\hline & & Seed Coating & 9.00 & 11.67 & 11.00 & 69.00 \\
\hline & \multirow{4}{*}{50} & Control & 17.00 & 20.50 & 22.00 & 40.50 \\
\hline & & Bio-Priming & 3.50 & 6.50 & 5.50 & 84.00 \\
\hline & & Priming & 14.50 & 17.50 & 20.50 & 46.50 \\
\hline & & Seed Coating & 8.50 & 10.33 & 10.00 & 73.00 \\
\hline & \multirow{4}{*}{75} & Control & 16.00 & 19.00 & 20.50 & 44.50 \\
\hline & & Bio-Priming & 3.00 & 5.33 & 4.50 & 88.00 \\
\hline & & Priming & 13.00 & 15.83 & 19.50 & 50.50 \\
\hline & & Seed Coating & 7.50 & 8.83 & 8.50 & 77.00 \\
\hline \multirow{16}{*}{ Master B } & \multirow{4}{*}{0} & Control & 18.50 & 20.00 & 16.00 & 36.50 \\
\hline & & Bio-Priming & 4.50 & 6.50 & 5.00 & 84.50 \\
\hline & & Priming & 16.50 & 18.00 & 14.50 & 43.00 \\
\hline & & Seed Coating & 8.00 & 10.00 & 8.50 & 66.00 \\
\hline & \multirow{4}{*}{25} & Control & 17.50 & 19.00 & 15.00 & 38.50 \\
\hline & & Bio-Priming & 3.50 & 5.00 & 3.50 & 88.00 \\
\hline & & Priming & 15.00 & 16.50 & 14.50 & 46.00 \\
\hline & & Seed Coating & 7.50 & 8.50 & 7.50 & 70.00 \\
\hline & \multirow{4}{*}{50} & Control & 16.00 & 17.50 & 14.00 & 44.00 \\
\hline & & Bio-Priming & 2.00 & 4.50 & 2.50 & 92.50 \\
\hline & & Priming & 12.50 & 16.50 & 13.00 & 51.00 \\
\hline & & Seed Coating & 5.50 & 7.50 & 5.50 & 74.00 \\
\hline & \multirow{4}{*}{75} & Control & 15.00 & 16.00 & 12.50 & 48.00 \\
\hline & & Bio-Priming & 1.50 & 3.50 & 2.50 & 96.50 \\
\hline & & Priming & 10.50 & 15.50 & 12.50 & 54.00 \\
\hline & & Seed Coating & 4.50 & 6.00 & 4.50 & 81.50 \\
\hline
\end{tabular}


Table 16. Effect of the integration between Cultivars, phosphors level and seed treatment on post-emergence damping off incidence percentage, root rot disease incidence percentage and survival plans percentage of pea during the second season 2015/2016.

\begin{tabular}{|c|c|c|c|c|c|c|}
\hline \multirow[t]{2}{*}{ Cultivars } & \multirow{2}{*}{$\begin{array}{l}\text { Phosphors } \\
\text { Level }\end{array}$} & \multirow[t]{2}{*}{ Seed treatments } & \multirow{2}{*}{$\begin{array}{l}\text { Post-emergence damping-off }(\%) \\
\text { Infection } \\
(\%)\end{array}$} & \multicolumn{2}{|c|}{ Root rot incidence (\%) } & \multirow{2}{*}{$\begin{array}{l}\text { Survival } \\
\text { Plant } \\
(\%)\end{array}$} \\
\hline & & & & $\begin{array}{l}\text { After } \\
40 \text { day }\end{array}$ & $\begin{array}{l}\text { After } \\
60 \text { day }\end{array}$ & \\
\hline \multirow{16}{*}{ Little Marvel } & \multirow{4}{*}{0} & Control & 23.17 & 24.83 & 23.17 & 29.83 \\
\hline & & Bio-Priming & 9.00 & 9.50 & 8.00 & 73.50 \\
\hline & & Priming & 21.50 & 22.00 & 21.50 & 35.00 \\
\hline & & Seed Coating & 12.00 & 15.00 & 16.50 & 56.50 \\
\hline & \multirow{4}{*}{25} & Control & 20.50 & 23.50 & 22.00 & 34.00 \\
\hline & & Bio-Priming & 8.50 & 7.50 & 7.00 & 77.00 \\
\hline & & Priming & 20.00 & 20.00 & 21.00 & 39.00 \\
\hline & & Seed Coating & 11.50 & 12.00 & 15.00 & 61.50 \\
\hline & \multirow{4}{*}{50} & Control & 19.00 & 20.00 & 20.00 & 41.00 \\
\hline & & Bio-Priming & 6.00 & 5.50 & 5.00 & 83.30 \\
\hline & & Priming & 16.50 & 17.00 & 17.50 & 49.00 \\
\hline & & Seed Coating & 10.00 & 10.00 & 12.00 & 68.00 \\
\hline & \multirow{4}{*}{75} & Control & 19.00 & 19.00 & 20.00 & 42.00 \\
\hline & & Bio-Priming & 5.00 & 6.00 & 5.00 & 84.00 \\
\hline & & Priming & 16.00 & 15.00 & 16.00 & 53.00 \\
\hline & & Seed Coating & 8.50 & 10.00 & 10.50 & 71.00 \\
\hline \multirow{16}{*}{ Master B } & \multirow{4}{*}{0} & Control & 20.00 & 20.50 & 19.00 & 39.50 \\
\hline & & Bio-Priming & 6.00 & 7.00 & 6.00 & 80.00 \\
\hline & & Priming & 18.00 & 18.50 & 16.50 & 46.00 \\
\hline & & Seed Coating & 10.00 & 11.50 & 10.50 & 67.00 \\
\hline & \multirow{4}{*}{25} & Control & 17.50 & 19.00 & 17.50 & 45.00 \\
\hline & & Bio-Priming & 5.00 & 5.00 & 5.00 & 84.00 \\
\hline & & Priming & 16.50 & 16.00 & 15.00 & 51.50 \\
\hline & & Seed Coating & 9.00 & 9.50 & 9.00 & 71.50 \\
\hline & \multirow{4}{*}{50} & Control & 17.00 & 17.50 & 16.00 & 48.50 \\
\hline & & Bio-Priming & 3.50 & 3.50 & 3.00 & 89.00 \\
\hline & & Priming & 14.50 & 14.00 & 13.00 & 57.50 \\
\hline & & Seed Coating & 8.50 & 8.00 & 7.00 & 75.50 \\
\hline & \multirow{4}{*}{75} & Control & 16.00 & 16.50 & 16.00 & 50.50 \\
\hline & & Bio-Priming & 3.00 & 3.50 & 3.50 & 89.00 \\
\hline & & Priming & 13.00 & 13.67 & 10.30 & 61.50 \\
\hline & & Seed Coating & 7.50 & 6.50 & 5.50 & 79.50 \\
\hline L.S.D at 0.05 & & & 0.07 & 0.20 & 0.07 & 0.14 \\
\hline
\end{tabular}


Table 17. Effect of the interaction between cultivars, phosphorus levels and seed treatments on post-emergence damping off incidence percentage, root rot disease incidence percentage and survival plans percentage of pea during the first season (2014/2015).

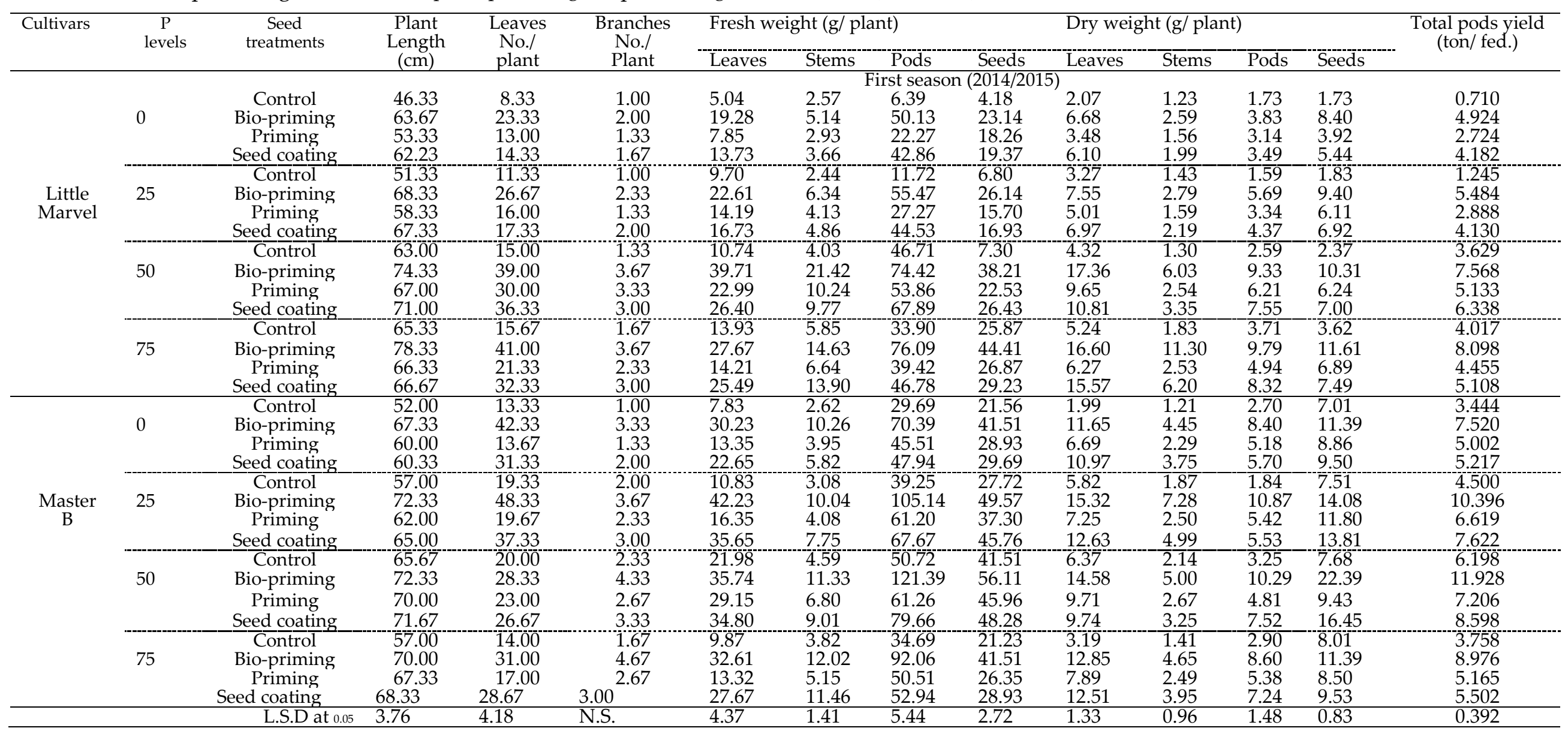


Table 18. Effect of the interaction between cultivars, phosphorus levels and seed treatments on vegetative growth and total pods yield of pea during the second season $(2015 / 2016)$

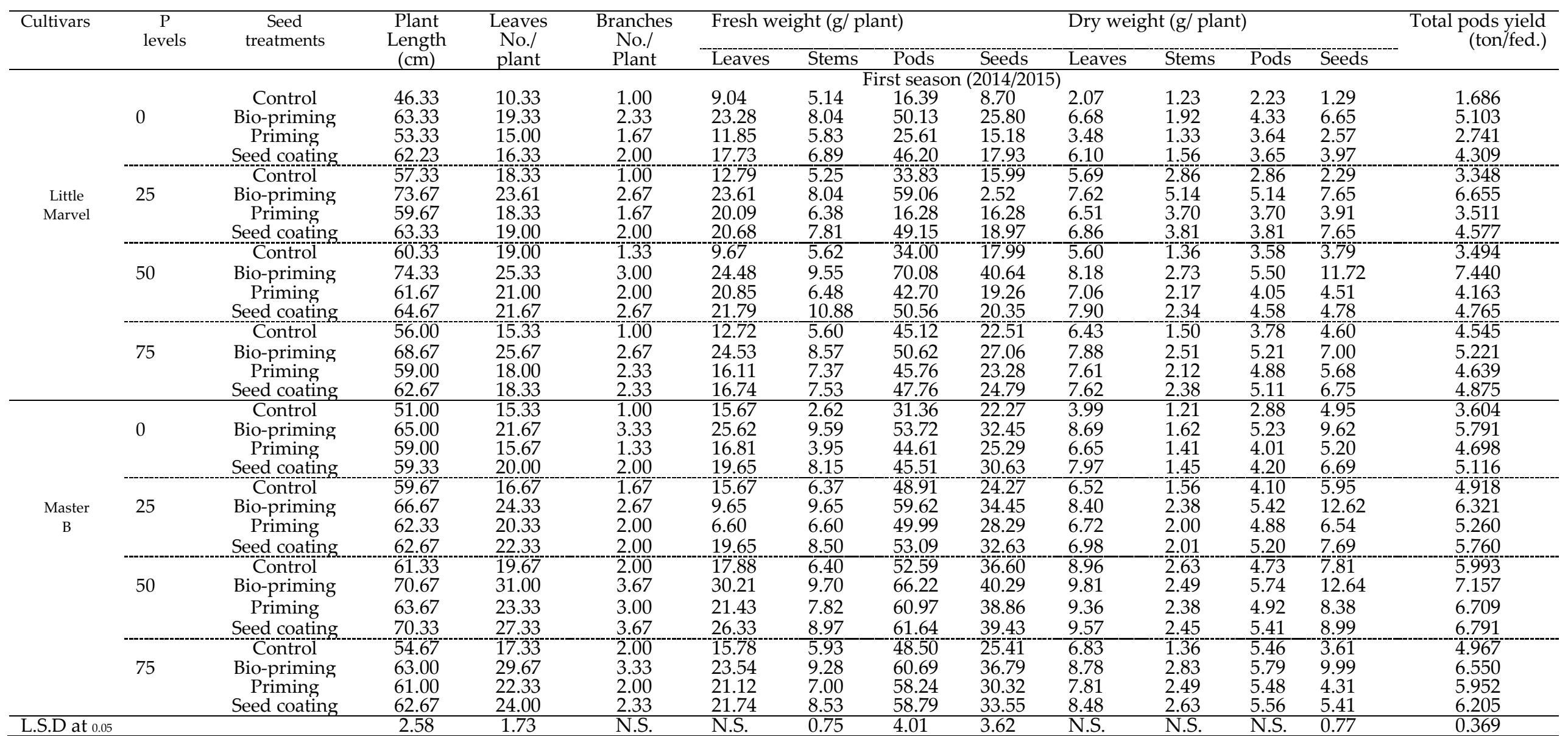




\section{REFERENCES}

Abd El-Kareem, F., 2002. Integrated treatments between bioagents and chitosan for controlling pea root rot disease under field conditions. Egypt. J. Appl. Sci. 17, 257-279.

Abda, K.A., Ali, H.Y., Mansour, M.S., 1992. Phytopathological studies on damping-off and root rot diseases of pea in A.R.E. Egypt. J. Appl. Sci. 7 (9), 242-261.

Agegnehu, G., 2009. Phosphate fertilizer and weed control effects on growth and yield of field pea on Nitisols of highland, Ethiopia. SINET: Ethiop. J. Sci. 32 (2), 1-8.

Badr, A., Ahmed, H.S., Hamouda, M., Badr, S.F., 2015. Genetic diversity among varieties and hybrid lines of pea (Pisum sativum L.) as Revealed by morphological traits and SSR markers. Egypt. J. Bot. 55 (1), 17- 29.

Barnett, H.L., Hunter, B.B., 1972. Illustrated Genera of Imperfect Fungi. 3rd ed., Burgess Publishing Company, Minneapolis, Minnesota, P-273.

Begum, M.M., Sariah, M., Puteh, A.B., Siddiqui, y., 2011. Field performance of bio primed seeds to suppress Colletotrichum truncotum causing damping off and seedling stand of soybean. Biol. Control. 53 (1), 18-23.

Benhamou, N., Kloepper, J.W., Tuzun. S., 1996. Induction of defense related ultra-structural modifications in pea tissue inoculated with entophytic bacteria. Plant Physiol. 112, 919-929.

Callan, N.W., Mathre, D.E., Miller, J.B., 1991. Field performance of sweet corn seed bio-primed and coated with Pseudomonas fluorescens AB254. Hort. Sci. 26, 1163-1165.

Contreras-Cornejo, H.A., Macías-Rodríguez, L. AlfaroCuevas, R., López-Bucio, J., 2014 b. Trichoderma spp. improves growth of Arabidopsis seedlings under salt stress through enhanced root development osmolite production, and $\mathrm{Na}+$ elimination through root exudates. Mol. Plant Microbe In. 27, 503-514.

Contreras-Cornejo, H.A., Macías-Rodríguez, L., CortésPenagos, C., López-Bucio, J., 2009. Trichoderma virens, a plant beneficial fungus, enhances biomass production and promotes lateral root growth through an auxin-dependent mechanism in Arabidopsis. Plant Physiol. 149, 1579-1592.

Contreras-Cornejo, H.A., Macías-Rodríguez, L., HerreraEstrella, A., López-Bucio, J., 2014 a. The 4phosphopantetheinyl transferase of Trichoderma virens plays a role in plant protection against Botrytis cinerea through volatile organic compound emission. Plant Soil. 379, 261-274.

Dass, A., Patnaik, U.S., Sudhishri, S., 2005. Response of vegetable pea (Pisum sativum) to sowing date and phosphorus under on farm condition. Ind. J. Agron. $50(1), 64-66$.

Demir, I., 2003. Effect of controlled hydration treatment on quality of aubergine (eggplant) seeds following storage. Phyton-Ann. Bot. A. 43, 307-317.

El-abd, S.O., Zaki, M.F., El-Mohamedy, R.S.R., Riad, G.S., 2013. Improving growth, fresh pod yield and quality, and controlling root rot and damping off of pea grown in sandy soil by integration effect of phosphorus fertilizer with biological seed treatments. Mid. East J. Agric. Res. 2 (1), 8-15.

El-Mohamedy R.S.R., AbdAlla, M.A., 2013. Bio-priming seed treatment for biological control of soil borne fungi causing root rot of green bean (Phaseolus vulgaris L.). J. Agric. Technol. 9 (3), 589-599.

EL-Mohamedy, R.S.R., 2004. Bio-priming of okra seed to control damping-off and root rot diseases. Ann. Agric Sci. Ain Shams Univ. 49 (11):339-356.

El-Mohamedy, R.S.R., Abd-El-Baky, M.M.H., 2008. Effects of seed treatment on control of root rot disease and improvement growth and yield of pea plants. Mid. East. Rus. J. Plant Sci. Biotechnol. 2 (1-2), 84-90.

El-Mohamedy, R.S.R., Abd-Alla, M.A., Badiaa, R.I., 2006. Soil amendment and bio- priming treatments as alternative fungicides for controlling root rot diseases on cowpea plants in Nobria province. Res. J. Agric. Biol. Sci. 2 (6), 391-398.

El-Mohamedy, R.S.R., Jabnoun-Khiareddine, H., DaamiRemadi, M., 2014. Control of root rot diseases of tomato plants caused by Fusarium solani, Rhizoctonia solani and Sclerotium rolfsii using different chemical plant resistance inducers. Tunis. J. Plant Prot. 9, 45-55.

Evanari, M., 1984. Seed Physiology: Its history from antiquity to the beginning of the 20th century. Bot. Rev. 50, 119142

Gilman, J.C., 1957. A Manual of Soil Fungi Revised 2nd Edition, Oxford and IBH publishing Company, Shahpur Jat, Delhi, P-220.

Giri, G.S., Schillinger, W.F., 2003. Seed priming winter wheat for germination, emergence and yield. Crop Sci. 43 , 2135-2141.

Gubbels, G.H., 1992. Effect of phosphorus rate and placement on the yield and cooking quality of field pea. Can. J. Plant Sci., 72 (1), 251-255.

Harman, G.E., Taylor, A.G., 1988. Improved seedling performance by integration of biological control agents at favorable $\mathrm{pH}$ levels with solid matrix priming. Phytopathology. 78, 520-525.

Harman, G.E., Howell, C.R., Viterbo, A., Chet, I., Lorito, M. 2004. Trichoderma species-opportunistic, avirulen plant symbionts. Nature Rev. Microbiol. 2, 43-56.

Heydecker, W., Higgins, J., Gulliver, R.L., 1973. Accelerated germination by osmotic seed treatment. Nature. 246, 42-44.

Hwang, S., Chang, K. Howard, R., Deneka, B., Turnball, G., 1996. Decrease in incidence of Pythuim damping-off of field peas by seed treatments with Bacillus spp. and metalaxyl. J. Plant Dis. Prot. 103, 31-41.

Jain, A., Singh, S., Kumar Sarma, B., Singh, H.B., 2012. Microbial consortium-mediated reprogramming of defence network in pea to enhance tolerance against Sclerotinia sclerotiorum. J. Appl. Microbiol. 112, 537550

Jensen, B., Knudsen, I.M., Madsen, M., Jensen, D.F., 2004. Biopriming of infected carrot seed with an antagonist, Clonostachys rosea, selected for control of seed borne Alternaria spp. Phytopathology. 94, 551-560.

Jones, J.P., Engelhard, A.W., Woltz, S.S., 1989. Management of Fusarium wilt of vegetables and ornamentals by macro- and micro element nutrition, in: Engelhard, A.W., (Eds.). Soilborne Plant Pathogens: Management of Diseases with Macro- and Microelements. The American Phytopathological Society, St. Paul, MN. P. $18-32$

Kalpana, M.H., Khan, A., Singh, A.K., Maurya, K.N., Sarwar, M., Yadava, R.K., Singh, U., Gautam, A.R. 2015. Effect of different seed priming treatments on germination, growth, biochemical changes and yield of wheat varieties under sodic soil. Int. J. Sci. Res. 4 (7), 3063010.

Karamanos, R.E., Flore, N.A., Harapiak, J.T., 2002. Response of field peas to phosphate fertilization. Can. J. Plant Sci. 83, 283-289.

Kaur, S., Gupta, A.K., Kaur, N., 2002. Effect of osmo- and hydro-priming of chickpea seeds on seedling growth and carbohydrate metabolism under water deficit stress. Plant Growth Regul. 37, 17-22.

Khan, A.A., 1992. Pre plant physiological seed conditioning. Hort. Rev. 14, 131-181.

Klute, A., 1986. Methods of Soil Analysis. Part 1 Physical and Mineralogical Methods. Soil Science Society of America, lnc. Publisher Madison, Wisconsin, pp. 500.

Kobriger, K.M., Hagedorn, D.J., 1983. Determination of bean root rot potential in vegetable production fields of Wisconsin's central sands. Plant Dis. 67 (2), 177-178.

Lacicowa, B., Pjeta, D., 1994. Protective effect of microbiological dressing of pea seeds (Pisum sativum) against pathogenic fungi living in soil. Ann. Univ. Maria Curie Sklodowska. 2, 165- 171

Lovatt, C.J., Mikkelsen, R.L., 2006. Phosphite fertilizers: what are they? Can you use them? Better Crops. 90 (4), 1113.

Malakooti, M.J., Nafisi, M., 1995. Fertilizer Utilization in Agricultural Lands "Irrigated and Dry Land Systems". 2nd ed. Tarbiate Modaress University Publications, Iran. pp. 90. 
Manore, D., Altaye, T., 2018. Effects of different level of phosphorous fertilizer on yield and yield component of field pea (Pisum sativum L.) varieties in Hadiya zone, Duna area, Southren Ethiopia. Asian J. Plant Sci. Res. 8 (2), 8-14.

Meena, S.K., Rakshit, A., Meena, V.S., 2016. Effect of seed biopriming and $\mathrm{N}$ doses under varied soil type on nitrogen use efficiency (NUE) of wheat (Triticum aestivum L.) under greenhouse conditions. Biocatal. Agric. Biotechnol. 6, 68-75.

Murat, E., Yildirim, B., Togay, N., Cig, F., 2009. Effect of phosphorus application and Rhizobium inoculation on the yield, nodulation and nutrient uptake in field pea (Pisum sativum sp. Arvense L.). J. Anim. Vet. Adv. 89 (2), 301-304.

Nadeem, A., Amjad, M., Anjum, M.A., 2003. Growth and yield response of pea (Pisum sativum L.) crop to phosphorus and potassium application. Pak. J. Sci. 40, 3-4.

Nayaka, S.C., Nironjana, S.R., Shankar, A.C., Mortensen, C.N., 2008. Seed bio priming with novel strain of Trichoderma harzianum for the control of toxigenic Fusarium verticillioides and fumonisin in maiza. Arch. Phytopathol. Plant Prot. 43 (3), 264-282.

Nelson, P.E., Tousun, T.A., Marasan, W.F.O., 1983. Fusarium spp. An Illustrated Manual for Identification, The Pennsylvania University Press, Pennsylvania, PP. 218

Osborn, R.M., Scharoth, M.N., 1989. Effect of osmopriming beet seed on germination rate and incidence of Pythium ultimum damping-off. Plant Dis. 73, 21-24.

Page, A.L., Miller, R.H., Keeney, D.R., 1982. Methods of Soil Analysis. Part 2. Chemical and Microbiological Properties, 2nd ed. Am. Soc. Agron. Inc. Soil Sci. Publ. Madis., Wisc., pp. 411-422.

Parsad, R.N., Multhoo, A.K., Mauryo, A.N., 1989. A note on the effect of phosphate fertilization on growth, nodulation and green pod yield of pea. Haryana J. Hort. Sci. 16, 142-144.

Persson, L., Bodker, L., Larsson-Wikstrom, M., 1997. Prevalence and pathogenicity of foot and root-rot pathogens of pea in Southern Scandinavia. Plant Dis. 81, 171-174.

Pill, W.G., Collins, C.M., Goldberger, B., Gregory, N., 2009. Responses of non-primed or primed seeds of 'Market more 76'cucumber (Cucumis sativus L.) slurry coated with Trichoderma species to planting in growth media infested with Pythium aphanidermatum. Sci. Hort. 121, 54-62.

Ragab, M.M., Aly, M.D.H., Ragab, M.M., El-Mougy, Nehal, S., 1999. Effects of fungicides, biocides and bio-agents on controlling pea root rot diseases. Egypt. J. Phytopathol. 27, 65-81.

Rakshit, A., Pal, S., Meena, S., Manjhee, B., Rai, S., Rai, A., Bhowmick, M.K., Singh, H.B., 2014. Seed bio-priming: a potential tool in integrated resource management. SATSA Mukh. Ann. Tech. Iss. 18, 94-103.

Rakshit, A., Pal, S., Rai, S., Rai, A., Bhowmick, M.K., Singh, H.B., 2013. Micronutrient seed priming: a potential tool in integrated nutrient management. SATSA Mukh. Ann. Tech. Iss. 17, 77-89.
Rakshit, A., Sunita, K., Pal, S., Singh, A., Singh, H.B., 2015. Biopriming mediated nutrient use efficiency of crop species. in: Rakshit, A., Singh, H.B., Sen, A., (Eds.), Nutrient Use Efficiency: from Basics to Advances, Springer India, pp-181-191.

Rauf, B.A., 2000. Seed borne disease problems of legume crops in Pakistan. Paki. J. Sci. Indust. Res. 43, 249-254.

Saxena, A., Raghuwanshi, R., Singh, H.B., 2015. Trichoderma species mediated differential tolerance against biotic stress of phytopathogens in Cicer arietinum L. J. Basic Microbiol. 55, 195-206.

Sharma, D.K., Yadav, A., Sharma, R., 1997. Effect of dates of sowing and phosphorus fertilization on growth, pod yield and disease incidence in (Pisum sativum L.). Ann. Agric. Res. 18, 546-566.

Singh, A., Jain, A., Sarma, B.K., Upadhyay, R.S., Singh, H.B., 2013 a. Rhizosphere microbes facilitate redox homeostasis in Cicer arietinum against biotic stress. Ann. Appl. Biol. 163, 33-46.

Singh, A., Sarma, B.K., Upadhyay, R.S., Singh, H.B., 2013 b. Compatible rhizosphere microbes mediated alleviation of biotic stress in chickpea through enhanced antioxidant and phenylpropanoid activities. Microbiol. Res. 168, 33-40.

Snedecore, W.C., Cochran, W.G., 1980. Statistical Methods. 7th ed. The Iowa State Univ. Press, Ames, Iowa, p- 95.

Srivastava, T.K., Ahlawat, I.P.S., Panwar, J.D.S., 1998. Effect of phosphorus, molybdenum and bio-fertilizers on productivity of pea (Pisum sativum L.). Ind. J. Plant Physiol. 3 (3), 237-239.

Taylor, A.G., Hadar, Y., Norton, J.M., Harman, A.A., 1985. Influence of pre sowing seed treatments of table beet on the susceptibility to damping - off caused by Pythium spp. Phytopathology. 73, 631-637.

Taylor, A.G., Klein, D.E., Whitlow, T.H., 1988. Solid matrix priming of seeds, Sci. Hort. 37, 1-11.

Togay, Y., Togay, N., Dogan, Y., 2008. Research on the effect of phosphorus and molybdenum applications on the yield and yield parameters in lentil (Lens culinaris medic.) Afr. J. Biotechnol. 7 (9), 1256-1260.

Tu, J.C., 1992. Management of root rot diseases of peas, beans and tomatoes. Can. J. Pant Pathol. 14, 92-99.

Verma, M.L., Bhandari, A.R., Raina, J.N., 1997. Effect of nitrogen and phosphorus application on the yield and macro-nutrient concentrations of pea (Pisum sativum L.). Int. J. Trop. Agric. 15, 195-198.

Vivek, S., Upadhyay, R.S., Sarma, B.K., Singh, H.B., 2016. Seed bio-priming with Trichoderma asperellum effectively modulate plant growth promotion in pea. Int. J. Agric Enviro. Biotechnol. 9 (3), 361-365

Warren, J.E., Bennett, M.A., 1999. Bio-osmopriming tomato (Lycopersicon esculentum Mill.) seeds for improved stand establishment. Seed Sci. Technol. 27 (2), 489-499.

We, L., 2000. Development of solid matrix priming to enhance loblolly pine (Pinus taeda) seed germination and analysis of its physiological mechanisms. Proc. Oklahoma Acad. Sci. 80, 33-37.

Xue, A.G., 2003. Biological control of pathogens causing root rot complex in field pea using Clonostachys rosea strain ACM 941. Phytopathology. 93, 329-335. 


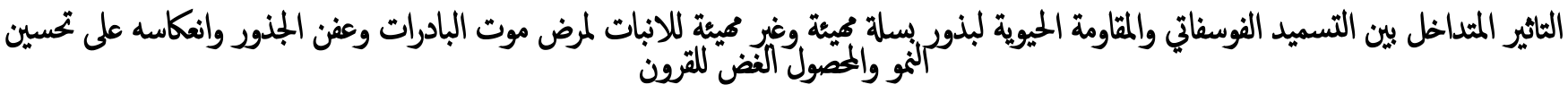

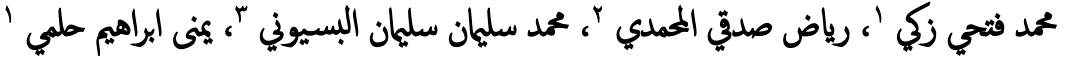

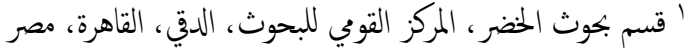

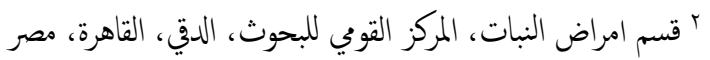

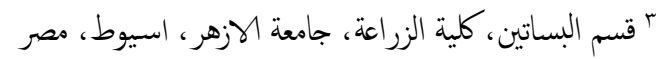

\section{الملخص العريي}

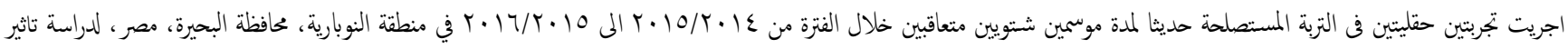

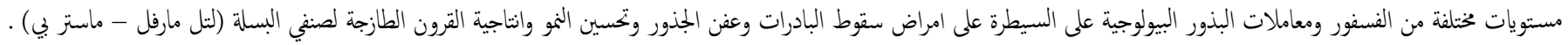

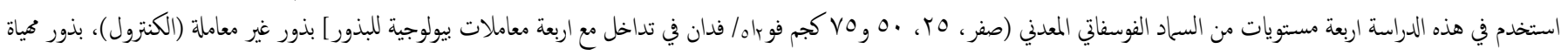

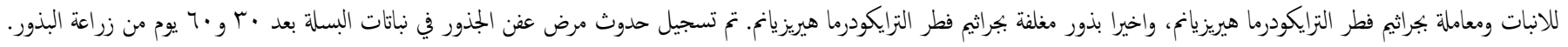

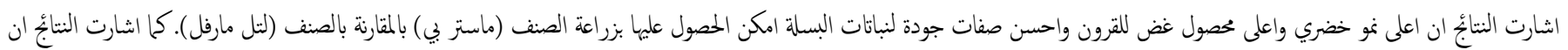

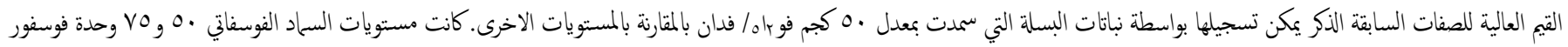

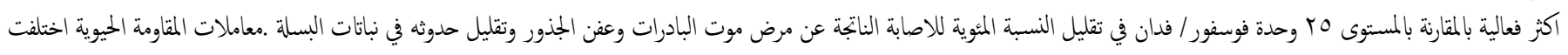

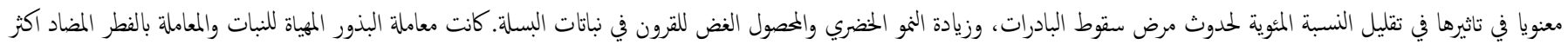

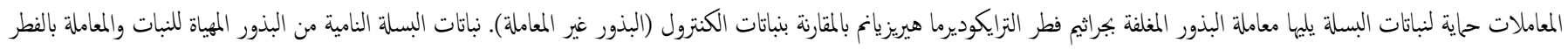

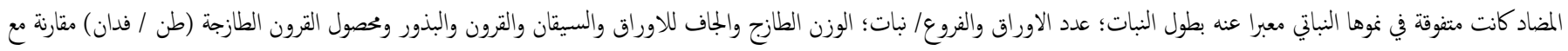

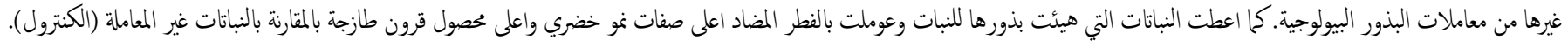

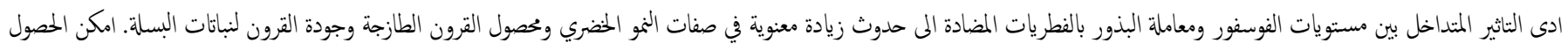

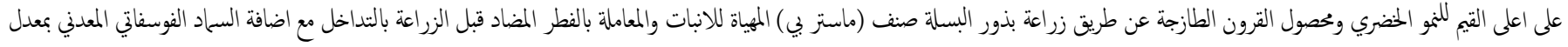

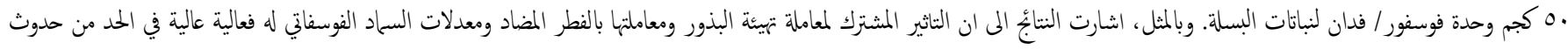

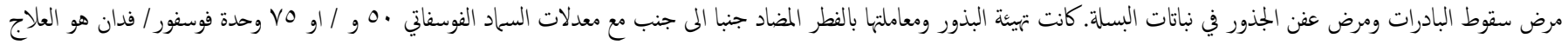
الفعال للغاية في تقليل النسبة المئوية للاصابة بالامراض التربة (موت البدرات وعفن الجذور) في البساتة. 